\title{
MODERNIZING JUDICIAL REVIEW OF THE Exercise of Prerogative Powers in Canada
}

\author{
JENNIFER A. KLINCK ${ }^{*}$
}

\begin{abstract}
Despite judicial pronouncements that the source of government power, whether statutory or prerogative, should not affect judicial review, Canadian courts respond much more tentatively when asked to review exercises of prerogative powers than exercises of statutory powers. Courts (1) define prerogative powers in a way that makes it difficult to precisely articulate their existence and scope; (2) frequently avoid judicially reviewing exercises of prerogative powers by applying peculiar justiciability tests; and (3) when they do engage in judicial review, generally limit themselves to a conservative form of procedural review. This article proposes that courts reform judicial review of the exercise of prerogative powers by (1) adopting a principled approach to defining prerogative powers that starts with distinguishing the Crown's prerogative powers from its natural person powers; (2) abandoning peculiar interest-based and subject matter justiciability tests in favour of a test that turns on the nature of the question, and maintaining a subject matter justiciability test only for exercises of prerogative powers that are integral to the democratic process; and (3) applying standard principles of administrative law to judicial review of the existence, scope, and exercise of prerogative powers.
\end{abstract}

\section{TABLE OF CONTENTS}

I. INTRODUCTION . . . . . . . . . . . . . . . . . . . . . . . . . . . . . . . . . . . . . 998

A. Overview of the Prerogative Powers . . . . . . . . . . . 998

B. Democratic Legitimacy and Rule of Law Deficiences . . . . 999

C. REFORMS TO JUdicial REVIEW OF THE EXERCISE OF

Prerogative Powers Animated by the Democratic

PRINCIPLE AND THE RULE OF LAW . . . . . . . . . . . . . . 1000

II. Defining the Prerogative . . . . . . . . . . . . . . . . . . . 1002

A. The Prerogative According to Dicey and Blackstone . . . 1002

B. PREFERRING DICEY OVER BLACKSTONE:

A Distinction Without a DifFERENCE? . . . . . . . . . . . . . . 1002

C. The Difference that Blackstone's Distinction Makes . . . 1003

D. Advantages of Natural Person Powers

OVER RESIDUAL LIBERTY . . . . . . . . . . . . . . . . . 1007

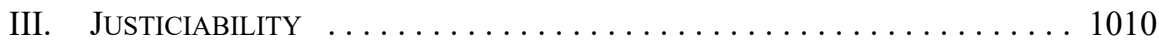

A. The BAsic Principle: Source of Power is IMMATERIAL $\ldots \ldots 1010$

B. InTEREST-BASED TESTS . . . . . . . . . . . . . . . . . . 1010

C. Subject Matter Tests $\ldots \ldots \ldots \ldots \ldots \ldots \ldots \ldots 10 \ldots \ldots \ldots \ldots$

IV. Standard AdMinistrative LAW PRINCIPLES . . . . . . . . . . . . . . 1021

A. Administrative LaW Judicial ReView PrinciPles . . . . . . . . 1022

BCL/LLB (McGill), LLM (Cambridge) is a lawyer at Power Law in Vancouver. Her litigation practice focuses on administrative and constitutional law, as well as appellate and Supreme Court of Canada advocacy. A version of this article was originally submitted as my LLM thesis at the University of Cambridge. I would like to thank the Canadian Institute for Advanced Legal Studies for generously supporting my LLM studies, as well as Dr. John Allison, for his rigour and encouragement as my thesis supervisor. 


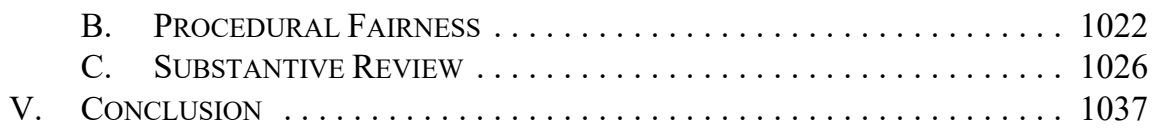

\section{INTRODUCTION}

Under the standard account of judicial review in Canadian administrative law, the role of courts is to mediate the "tension between the rule of law and the foundational democratic principle" that arises when Parliament and legislatures endow administrative bodies with statutory powers. ${ }^{1}$ Courts manage this tension by ensuring that public authorities do not exceed their statutory powers, while also showing "deference to administrative decisions within the area of decision-making authority conferred" by statute. ${ }^{2}$ However, Canadian courts and commentators have yet to articulate an approach to judicial review animated by a commitment to democracy and the rule of law which is suited to reviewing executive actions under the Crown's non-statutory prerogative powers.

\section{A. Overview of the Prerogative Powers}

The Crown's prerogative powers are defined at common law. ${ }^{3}$ As such, they can be limited or displaced by statute, absent exceptional constitutional entrenchment. ${ }^{4}$ Although "legislation has severely curtailed the scope of the Crown prerogative" in Canada, ${ }^{5}$ it remains important in a number of areas. The prerogative vests the executive with substantial discretionary authority to conduct a range of activities from "mundane administrative" affairs to "key matters of state." ${ }^{\prime 6}$ For example, the executive still relies on the prerogative to confer or revoke honours, ${ }^{7}$ passports, ${ }^{8}$ and pardons,${ }^{9}$ to exercise prosecutorial discretion, ${ }^{10}$ to appoint

Dunsmuir v New Brunswick, 2008 SCC 9, [2008] 1 SCR 190 at para 27 [Dunsmuir].

Alberta (Information and Privacy Commissioner) v Alberta Teachers'Association, 2011 SCC 61, [2011]

3 SCR 654 at para 1 [ATA]. See also Dunsmuir, ibid at paras 27-28.

Black v Canada (Prime Minister) (2001), 54 OR (3d) 215 at para 26 (CA) [Black].

Pursuant to section 41(a) of the Constitution Act, 1982, being Schedule B to the Canada Act 1982 (UK), 1982, c 11, an amendment to the Constitution of Canada in relation to "the office of the Queen, the Governor General and the Lieutenant Governor of a province" can only be made with the unanimous consent of the Senate, the House of Commons, and the legislative assembly of each province. If certain prerogative powers are intrinsic or essential to the office of the Queen, the Governor General, or the Lieutenant Governor of a province (one possible example might be the power to assent to bills), those powers may be constitutionally entrenched and only subject to amendment by way of the unanimous formula for constitutional amendment (see Reference re Supreme Court Act, ss 5 and 6, 2014 SCC 21, [2014] 1 SCR 433).

$5 \quad$ Black, supra note 3 at para 27.

$6 \quad$ Philippe Lagassé, "Parliamentary and Judicial Ambivalence Toward Executive Prerogative Powers in Canada" (2012) 55:2 Can Public Administration 157 at 162.

See e.g. Black, supra note 3.

Kamel v Canada (Attorney General), 2009 FCA 21, [2009] 4 FCR 449 at paras 21-23, leave to appeal to SCC refused, 33088 (20 August 2009) [Kamel].

9 Hinse v Canada (Attorney General), 2015 SCC 35, [2015] 2 SCR 621 at paras 27-31 [Hinse]; Criminal Code, RSC 1985, c C-46, s 749. 
ministers ${ }^{11}$ and dissolve Parliament, ${ }^{12}$ to declare war and deploy troops, ${ }^{13}$ to engage in diplomacy, ${ }^{14}$ and to conclude international treaties ${ }^{15}$ and treaties with First Nations. ${ }^{16}$

Prerogative powers may be exercised directly by the Governor General, the Prime Minister, and other ministers of the Crown. ${ }^{17}$ Moreover, public bodies may be established and delegated powers pursuant to the exercise of prerogative powers. ${ }^{18}$ Similar principles apply in the provinces, where the Lieutenant-Governors have all the prerogative powers necessary to fulfill provincial purposes. ${ }^{19}$

While uncontentious examples of prerogative powers can be identified, as will be seen, adequately defining them as a class is controversial and uncertain. The prerogative powers have never been comprehensively catalogued, nor has a definition that would enable all assertions of the existence and scope of a prerogative power to be decided without controversy ever been articulated. ${ }^{20}$

\section{B. DEMOCRATIC LEGITIMACY AND RULE OF LAW DEFICIENCIES}

Despite their continuing importance, significant criticisms have been levelled against the prerogative powers. They have been described as anachronistic; ${ }^{21}$ as obscure, uncertain and vague; ${ }^{22}$ and as suffering from "a democratic deficit. ${ }^{, 23}$ In 1994, British politician Jack Straw even affirmed that " $[\mathrm{t}]$ he royal prerogative has no place in a modern western democracy." 24 Indeed, the idea that the government may act without statutory authorization, invoking illdefined common law powers, sits uncomfortably with contemporary conceptions of democratic legitimacy and the rule of law.

Non-statutory sources of government authority do not have the same democratic pedigree as statutory sources, even though ministerial accountability to Parliament and provincial

Guergis v Novak, 2013 ONCA 449, 116 OR (3d) 280 [Guergis].

Conacher v Canada (Prime Minister), 2010 FCA 131, [2011] 4 FCR 22, leave to appeal to SCC refused, 33848 (20 January 2011) [Conacher].

Blanco v Canada, 2003 FCT 263, 231 FTR 3 [Blanco]; Turp v Chrétien, 2003 FCT 301, 111 CRR (2d) 184 [Turp 2003].

Copello v Canada (Minister of Foreign Affairs), 2003 FCA 295, 308 NR 175 at paras 21-22.

Turp v Canada (Justice), 2012 FC 893, [2014] 1 FCR 439 [Turp 2012].

Cook $v$ The Minister of Aboriginal Relations and Reconciliation, 2007 BCSC 1722, [2008] 7 WWR 672 [Cook].

Black, supra note 3 at para 32.

See McDonald v Anishinabek Police Service (2006), 83 OR (3d) 132 (Sup Ct J (Div Ct)) [Anishinabek]. See Liquidators of the Maritime Bank of Canada v Receiver-General of New Brunswick, [1892] AC 437 (PC).

Paul Lordon, Crown Law (Markham: Butterworths, 1991) at 62; AW Bradley, KD Ewing \& CJS Knight, Constitutional and Administrative Law, 16th ed (Harlow: Pearson, 2015) at 253; $R v$ Secretary of State for the Home Department, Ex parte Northumbria Police Authority, [1989] 1 QB 26 at 56 (CA) [Northumbria Police].

UK, HC, Official Report, vol 223, col 489 (21 April 1993) (John Garrett), cited in Sebastian Payne, "The Royal Prerogative" in Maurice Sunkin \& Sebastian Payne, eds, The Nature of the Crown: A Legal and Political Analysis (Oxford: Oxford University Press, 1999) at 77.

UK, HC, "Taming the Prerogative: Strengthening Ministerial Accountability to Parliament," Cm 422 in Sessional Papers (2003-04) 1 at 5 [Taming the Prerogative]; Margit Cohn, "Judicial Review of NonStatutory Executive Powers after Bancoult: A Unified Anxious Model” [2009] Public L 260 at 265. Cohn, ibid.

Jack Straw, "Abolish the Royal Prerogative" in Anthony Barnett, ed, Power and the Throne: The Monarchy Debate (London: Vintage, 1994) 125 at 125. 
legislatures provides a degree of democratic oversight over the exercise of prerogative powers. ${ }^{25}$ Prior statutory authorization for government action entails Parliamentary debate and scrutiny of the nature and scope of government power. Moreover, the existence of publicly available written instruments defining the scope of government powers enhances transparency. ${ }^{26}$

To the extent that prerogative powers are uncertain and vaguely defined, they are also difficult to square with the rule of law. The principle of legality inherent in the rule of law requires "that the executive must be able to demonstrate a lawful authority for its actions, whether under statute, common law or prerogative." 27 The rule of law further requires that these sources of authority prescribe the limits of lawful government action, which are enforced by the courts through judicial review. ${ }^{28}$ If the prerogative powers remain nebulous, they cannot provide the defined legal authority, with boundaries able to be monitored by courts, that the rule of law demands.

Notwithstanding these democratic legitimacy and rule of law deficiencies, governments defend the prerogative powers on the grounds that they are "a well-established part of the constitution," offer "much-needed flexibility to govern" and allow ministers "to react quickly in possibly complex and dangerous circumstances." 29 The democratic principle and the rule of law require a healthy skepticism towards such claims. Legislation, too, can confer upon government actors broad discretionary powers allowing them to address important and complex problems; at the same time, an explicit statutory foundation enhances democratic accountability and provides a concrete basis for determining the limits of government authority. Still, it is true that statutes may not adequately foresee all the powers governments need to act in the public interest, and it may not always be practicable to obtain statutory authorization in advance of necessary government action.

\section{REFORMS TO JUDICIAL REVIEW OF THE EXERCISE OF Prerogative Powers Animated by the Democratic Principle AND THE RULe OF LAW}

One way to mitigate the democratic legitimacy and rule of law deficiencies associated with prerogative powers is to codify them. In the United Kingdom, the question of whether some or all of the prerogative powers should be codified has been the subject of lively debate and legislative proposals, as well as government and parliamentary reports. ${ }^{30}$ In Canada, however, systematic codification and modernization of the prerogative have not figured prominently on the political agenda. Additionally, since prerogative powers have been a long-standing feature of the British conception of the State, they are interwoven into existing legislation, institutions, and governance practices. Consequently, systematic codification

Peter W Hogg, Constitutional Law of Canada, 5th ed (Toronto: Carswell, 2007) (loose-leaf 2016 supplement), ch 9 at $13-15$.

Cohn, supra note 22 at 265 .

27 Anthony Lester \& Matthew Weait, "The Use of Ministerial Powers Without Parliamentary Authority: The Ram Doctrine" [2003] Public L 415 at 419.

Dunsmuir, supra note 1 at para 28.

See e.g. UK, Ministry of Justice, The Governance of Britain: Review of the Executive Royal Prerogative Powers: Final Report (London: Ministry of Justice, 2009) at para 8.

See ibid at paras 6-16. 
could require intensive reviews in order to avoid creating unanticipated lacunae, the cost of which may be difficult to justify since the established system works relatively well, and can be modified with targeted legislation or policies to enhance accountability in areas of particular concern. ${ }^{31}$

Nevertheless, it is possible for courts to moderate some of these democratic and rule of law deficiencies by adopting incremental reforms to judicial review of the exercise of prerogative powers (while remaining sensitive to claims that some measure of non-statutory executive action is necessary). ${ }^{32}$

At present, however, Canadian courts respond much more tentatively when asked to review exercises of prerogative powers than exercises of statutory powers. Canadian courts (1) define prerogative powers in a way that makes it difficult to precisely articulate their existence and scope; (2) frequently avoid judicially reviewing exercises of prerogative powers by applying peculiar justiciability tests; and (3) when they do engage in judicial review, generally limit themselves to a conservative form of procedural review. Courts adopt this tentative approach despite judicial pronouncements that the source of government power, whether statutory or prerogative, should not affect judicial review. ${ }^{33}$

I will argue that the principles governing judicial review of the exercise of prerogative powers need to be clarified and brought into line with the principles that apply to judicial review of statutory powers. Where possible, principles that mitigate the prerogative powers' democratic legitimacy and rule of law deficiencies should be preferred. To this end, I will propose the following three reforms:

- First, courts should abandon the misconception that the distinction between the Crown's unique powers and its natural person powers is of no practical significance. This distinction is needed to determine the existence and scope of the Crown's non-statutory powers.

- Second, courts should discard flawed justiciability tests, which are disproportionately applied to prerogative powers.

- Third, when reviewing the exercise of prerogative powers, courts should use the same principles that apply to judicial review of statutory powers. To the extent that this approach will require courts to more explicitly define the nature and purpose of particular prerogative powers, courts should engage in this project.

For a discussion of this issue in the British context, see ibid at paras 109-12. In Canada, national defence provides a good example of a situation where prerogative powers operate together with primary and secondary legislation (in particular the National Defence Act, RSC 1985, c N-5 and its associated regulations) to provide authority for the existence, organization, and activities of the armed forces. As an example of a targeted measure to increase accountability, the federal government has adopted a "Policy on Tabling of Treaties in Parliament," which provides that international instruments are to be tabled in the House of Commons, accompanied by a brief Explanatory Memorandum, following their signature or adoption by other procedure and prior to Canada formally notifying that it is bound by the instrument (Global Affairs Canada, "Policy on Tabling of Treaties in Parliament," (Ottawa: GAC, 6 April 2006) at para 4).

Cohn, supra note 22 at $265-66$.

Hupacasath First Nation v Canada (Minister of Foreign Affairs), 2015 FCA 4, 379 DLR (4th) 737 at para 63 [Hupacasath]; Black, supra note 3 at para 47. 


\section{Defining the Prerogative}

\section{A. The Prerogative According to DICEY AND BLACKSTONE}

The royal prerogative is "a notoriously difficult concept to define adequately." ${ }^{34}$ Two classic competing definitions are those offered by A.V. Dicey and Sir William Blackstone. Dicey defined the prerogative as "the residue of discretionary or arbitrary authority, which at any given time is legally left in the hands of the Crown." ${ }^{35}$ On this view, "[e]very act which the executive government can lawfully do without the authority of an Act of Parliament is done in virtue of this prerogative." ${ }^{36}$ For Blackstone, the monarch's "special pre-eminence ... in right of his regal dignity" is essential to the prerogative. ${ }^{37}$ As such, the designation of royal prerogative "can only be applied to those rights and capacities which the king enjoys alone, in contradistinction to others, and not to those which he enjoys in common with any of his subjects." 38

Canadian jurisprudence has generally preferred Dicey's definition over Blackstone's. The Supreme Court of Canada ${ }^{39}$ and other Canadian appellate courts ${ }^{40}$ have endorsed Dicey's definition, while the British Columbia Court of Appeal has expressly rejected Blackstone's. ${ }^{41}$ Pursuant to these authorities, all non-statutory Crown powers are prerogative powers. ${ }^{42}$ If Dicey has prevailed in Canadian courts, this is due to a perception that there are no practical consequences to retaining Blackstone's distinction. Contrary to this view, it will be shown that Blackstone's distinction must be retained, because it is essential for determining the existence and scope of the Crown's non-statutory powers.

\section{B. Preferring Dicey OVER BLACKSTONE: A Distinction Without a Difference?}

A primary justification for adopting Dicey's definition is that "there is no practical significance to the distinction between prerogative powers and natural person powers since, in either case, the power is reviewable by the court." ${ }^{\text {"3 }}$ If the source of the Crown's powers determined the availability of judicial review, distinguishing sources of power would be important. Sir William Wade defended Blackstone's definition on the grounds that "[i]t may

Taming the Prerogative, supra note 22 at para 3, cited in Bradley, Ewing \& Knight, supra note 20 at 250.

AV Dicey, The Law of the Constitution, ed by JWF Allison (Oxford: Oxford University Press, 2013) at 188 .

Ibid at 189

Sir William Blackstone, Commentaries on the Laws of England in Four Books, 11th ed (London: A Strahan \& W Woodfall, 1791) Book I at 239.

Ibid.

See Canada (Prime Minister) v Khadr, 2010 SCC 3, [2010] 1 SCR 44 at para 34 [Khadr]; Ross River Dena Council Band v Canada, 2002 SCC 54, [2002] 2 SCR 816 at para 54. Earlier, in Quebec (AG) $v$ Labrecque, [1980] 2 SCR 1057 at 1082 [Labrecque], the Court endorsed Blackstone's definition.

See e.g. Askin v Law Society of British Columbia, 2013 BCCA 233, 363 DLR (4th) 706 at para 34, leave to appeal to SCC refused, 35463 (7 November 2013) [Askin]; Black, supra note 3 at para 25.

Delivery Drugs Ltd v Ballem, 2007 BCCA 550, 286 DLR (4th) 630 at paras 50-53, leave to appeal to SCC refused, 32428 (3 April 2008).

Ibid at para 53 .

Anishinabek, supra note 18 at para 67, citing Council of Civil Service Unions v Minister for the Civil Service, [1985] 1 AC 374 at 409-10 (HL) [CCSU]. See also Peter W Hogg \& Patrick J Monahan, Liability of the Crown, 3rd ed (Toronto: Carswell, 2000) at 16. 
well be easier to extend [judicial] control to the few genuine prerogative powers ... if the court is not by the same token committed to extend it to all sorts of pretended prerogatives." ${ }^{\prime 4}$ In an apparent contradiction, Wade suggested elsewhere that the true prerogatives would remain unreviewable, even as courts extended judicial review to those powers the Crown "shares with everyone else." 45 While pointing in opposite directions, both defences of Blackstone rely on the expectation that the availability of judicial review would depend upon the source of power. Once the possibility of judicial review is extended to all exercises of non-statutory powers, such arguments lose their force. Wade himself subsequently admitted that the House of Lords' holding that the source of power is irrelevant to the availability of judicial review "may, indeed, be regarded as ruling out the distinction which Blackstone made. $" 46$

At one time, it was also suggested that Blackstone's distinction might affect the availability of public law claims, "since a wide definition of the prerogative may bring into the public law forum matters that would otherwise be private law issues." has not turned out to be the case. Whether public or private law claims are available does not turn on the distinction between the Crown's prerogative powers and its natural person powers, but on a contextual inquiry into the public or private nature of a particular government action. ${ }^{48}$

\section{THE DIFFERENCE THAT BLACKSTONE's DisTinCTION MAKES}

Distinguishing the Crown's unique powers from those it shares with natural persons is therefore irrelevant to the availability of judicial review or public law claims. These considerations, however, are inadequate to support the conclusion that nothing practical now turns on the distinction, so that Dicey's definition may safely be adopted. Rather, adopting a definition of prerogative powers that includes all non-statutory powers of the Crown generates significant practical problems for determining their existence and scope. Dicey's definition "does not take us very far" 49 in determining whether an asserted prerogative power exists, because it "does not provide criteria by which one could identify something as falling within the class of prerogatives." ${ }^{50}$ Worse, taking Dicey's definition too seriously risks eroding courts' ability to identify the limits of non-statutory powers and generating unnecessary confusion when prerogative powers are codified.

\section{DELINEATING THE BOUNDARIES OF PREROGATIVE POWERS}

If courts understand "the Crown's non-statutory powers" as a comprehensive definition of the prerogative, they may find it difficult or impossible to inquire into the existence of

Sir William Wade, Constitutional Fundamentals, revised ed (London: Stevens \& Sons, 1989) at 62. HWR Wade, "Procedure and Prerogative in Public Law" (1985) 101 Law Q Rev 180 at 198.

Sir William Wade, "The Crown, Ministers and Officials: Legal Status and Liability" in Sunkin \& Payne, supra note 21 at 31 .

Lordon, supra note 20 at 63.

Air Canada v Toronto Port Authority, 2011 FCA 347, [2013] 3 FCR 605 at paras 56-60.

Burmah Oil Co Ltd v Lord Advocate, [1965] AC 75 (HL (Scot)) at 99, Reid L [Burmah Oil].

Payne, supra note 21 at 94. 
asserted prerogative powers. Absent some other criteria for identifying prerogative powers, courts may conclude (or at least imply) that every government action not authorized by statute is - for that reason — authorized by the prerogative.

The Ontario Court of Appeal appeared to reason in this way in Black. ${ }^{51}$ In that case, Black "sued the Prime Minister for abuse of power, misfeasance in public office and negligence," alleging that the Prime Minister had unlawfully and wrongfully intervened with the Queen to oppose his appointment as a peer in the United Kingdom. ${ }^{52}$ Black claimed that the Prime Minister's communication with the Queen fell outside the scope of the prerogative because it was a "personal intervention" motivated by a "personal vendetta." 53 Citing Dicey's definition of the prerogative, ${ }^{54}$ the Court responded that "the Prime Minister's authority is always derived from either a federal statute or the prerogative; it is never personal in nature.... Here, Prime Minister Chrétien did not act under a statute; he therefore acted under the authority of the Crown prerogative." ${ }^{55}$ The implication of this statement is that if the Prime Minister acted in fact, and did not act under a statute, he must have acted under the prerogative. Such reasoning would preclude the possibility of finding that the Prime Minister had acted outside the scope of his legal authority.

The reasoning suggested by the Court's statement in Black must be rejected as incompatible with the constitutional guarantee of judicial review, "particularly with regard to the definition and enforcement of jurisdictional limits." ${ }^{.6}$ It offends the unwritten constitutional principle of the rule of law, by virtue of which "all exercises of public authority must find their source in law" and "[a]ll decision-making powers have legal limits, derived from the enabling statute itself, the common or civil law or the Constitution." 57

In fairness, the Court of Appeal's recourse to Dicey's definition was not the sole basis for its conclusion that the Prime Minister had acted under the prerogative. The Court also concluded that the prerogative power relating to honours included the power of giving advice on and advising against a foreign country's conferral of honours on a Canadian citizen because, if it did not, Canada's three policy statements on the issue would be meaningless. ${ }^{58}$

Nevertheless, Dicey's definition was not helpful to the Court's analysis, but was rather a source of confusion in defining the scope of the prerogative powers. By itself, Dicey's definition does not enable courts to perform their judicial review function of defining and enforcing the limits of executive power, because it does not provide courts with any device for identifying or delineating the scope of prerogative powers.

\footnotetext{
Supra note 3.

Ibid at para 1 .

Ibid at para 39

Ibid at paras $25,39$.

Ibid at para 39 [citation omitted] [emphasis added]. As Lorne Sossin points out, this conclusion seems open to challenge (Lorne Sossin, "The Rule of Law and the Justiciability of Prerogative Powers: A Comment on Black v Chrétien" (2002) 47:2 McGill LJ 435 at 442-43 [Sossin, "Rule of Law"]).

Dunsmuir, supra note 1 at para 31.

Ibid at para 28 .

Black, supra note 3 at para 37.
} 


\section{CONFUSING CODIFICATION}

Defining the prerogative as "the Crown's non-statutory powers" may also cause unnecessary confusion when a prerogative power is codified. Courts occasionally say that despite a traditional prerogative power having been given a statutory basis, the power retains its prerogative nature. For example, section 579 of the Criminal Code ${ }^{59}$ now provides statutory authority for the Attorney General's power to stay a criminal proceeding, which is of the same nature as the Crown's traditional prerogative power (also exercised by the Attorney General) to stay a criminal proceeding by filing a nolle prosequi. ${ }^{60}$ Despite this statutory basis, the power to stay a criminal proceeding continues to be referred to as a prerogative power, ${ }^{61}$ and courts interpret section 579 with reference to the prerogative power to file a nolle prosequi. ${ }^{62}$ This judicial treatment reflects the uncontroversial conclusion that Parliament, in enacting section 579, intended to preserve the character and scope of the prerogative power to file a nolle prosequi. ${ }^{63}$ However, the idea that a prerogative power that is given a statutory basis should retain its prerogative nature is incomprehensible if Dicey's definition of the prerogative is taken to be exhaustive, that is, if the only defining feature of a prerogative power is that it is a power whose source is not statutory.

\section{BLACKSTONE'S DisTinCTION: SELECTING CRITERIA FOR THE EXISTENCE OF AN ALLEGED POWER}

Considering these difficulties, courts must go beyond Dicey for an adequate definition of the prerogative. What is required are criteria for courts to apply when answering the questions "does the Crown have the power it asserts?" and "what is the scope of the Crown's asserted power?" Although Blackstone's definition does not furnish such criteria, his distinction between the Crown's unique powers and its natural person powers determines which criteria apply. Thus, Blackstone's distinction is crucial as the starting point of the inquiry.

Where the Crown's natural person powers are at issue, the existence and scope of the asserted power is determined through a process of analogy to a natural person. The Crown has the "general capacity" of a physical person "in accordance with the rule of ordinary law." ${ }^{64}$ Thus, if the action is something that a natural person could do, then it will fall within the scope of the Crown's natural person powers. ${ }^{65}$ Examples include the powers to contract, and to acquire and dispose of property. ${ }^{66}$

Supra note 9 .

R v Mann, 2014 BCCA 231, 310 CCC (3d) 143 at paras 34-39 [Mann], leave to appeal to SCC refused, 36066 (18 December 2014).

See e.g. Dubé c R, 2009 QCCS 6749, 2009 QCCS 6749 (CanLII) at para 7 [Dubé].

Mann, supra note 60 at paras 34-39; Dubé, ibid at paras 7-8.

See e.g. Hinse, supra note 9, where the Supreme Court of Canada reiterated that the statutory provisions codifying the prerogative of mercy "merely set out various ways to exercise this prerogative but do not limit its scope" (ibid at para 30, citing Therrien (Re), 2001 SCC 35, [2001] 2 SCR 3 at para 113). Labrecque, supra note 39 at 1082.

George Winterton, Parliament, the Executive and the Governor-General (Melbourne: Melbourne University Press, 1983) at 121-22.

Labrecque, supra note 39 at 1082; Cook, supra note 16 at para 52. 
Where the Crown asserts powers that are unique to it, "the proper approach is a historical one." ${ }^{67}$ The court must look to historical precedent to determine the existence and extent of the asserted power. This historical approach implements the principle that courts should not extend the Crown's exceptional common law powers, ${ }^{68}$ as "it is 350 years and a civil war too late for the Queen's courts to broaden the prerogative." $" 69$ That being said, a historical approach can involve considerable uncertainty where a prerogative power is not established in contemporary case law or government practice. The failure of old cases or textbooks to mention a prerogative power may reflect its non-existence or, alternatively, the fact that its existence was seen as too evident to merit mention. ${ }^{70}$ The historical position may be not only difficult to discover, but also ambiguous. England's seventeenth century power struggle between the King and Parliament, culminating in the imposition of formal legal constraints on the King's prerogative through the Bill of Rights, $1689,{ }^{71}$ may be seen as a cut-off excluding earlier historical precedents for broad royal prerogatives. ${ }^{72}$ Nevertheless, the scope of the Crown's prerogative powers was never fixed, but fluctuated over time ${ }^{73}$ and was contested based on competing political theories. ${ }^{74}$ Therefore, while history provides criteria for identifying the Crown's unique powers, it may not provide clear answers in particular cases. Considering the rule of law and democratic legitimacy deficiencies associated with prerogative powers, where there are competing historical authorities, the executive should be expected to demonstrate that obtaining statutory authorization would not be practicable before the existence of a disputed prerogative power is recognized. Similar demonstration should also be expected where the executive advances a novel interpretation of an established prerogative power. As I will argue below, courts should show deference to the executive's determinations in this regard, since standard administrative law principles would typically require courts to review executive determinations of the existence and scope of a prerogative power on a reasonableness standard, as they do for executive interpretations of their enabling legislation.

\section{BLACKSTONE'S DISTINCTION: \\ INHERENT CONSTRAINTS ON NATURAL PERSON POWERS}

Mark Elliott and BV Harris characterize the distinction between the Crown's prerogative and natural person powers as a distinction between the prerogative as opposed to "de facto" 75 or "third source" powers. ${ }^{76}$ They present prerogative powers as grounded in positive legal authority and de facto or third source powers as a residual liberty, pursuant to which "the government is free to do anything that does not interfere with the judicially-enforceable rights of others and is not otherwise legally prohibited.",77

Burmah Oil, supra note 49 at 101, Reid L. See also Payne, supra note 21 at 94-95. Labrecque, supra note 39 at 1083.

British Broadcasting Corp v Johns, [1965] 1 Ch 32 at 79 (CA), Diplock LJ.

See Northumbria Police, supra note 20 at 58, Nourse LJ.

(UK), 1 Will \& Mar, c 2.

Bradley, Ewing \& Knight, supra note 20 at 251-52.

Burmah Oil, supra note 49 at 100 , Reid L.

Payne, supra note 21 at 101.

Mark Elliott, The Constitutional Foundations of Judicial Review (London: Hart, 2001) at 166-67 [emphasis in original].

BV Harris, "The 'Third Source' of Authority for Government Action" (1992) 108:4 Law Q Rev 626 at 626; BV Harris, "The 'Third Source' of Authority for Government Action Revisited" (2007) 123:2 Law Q Rev 225 at 225-27 [Harris, "Revisited"].

Harris, "Revisited," ibid at 235. 
Their characterization illuminates a further way, beyond the method of identification, in which Blackstone's distinction is required to establish the scope of the Crown's non-statutory powers. Whereas the Crown's prerogative powers may extend to "authori[zing] the government to override competing common law legal rights," "78 the legal rights of others and the general law form a hard boundary constraining the scope of the Crown's natural person powers. ${ }^{79}$ However, if courts ignore the distinction between these two categories of nonstatutory Crown powers, they can be expected to lose sight of this basic difference between the scope of each.

The British Columbia Court of Appeal's treatment of the Crown's authority to establish a non-statutory program to reimburse the cost of certain prescription drugs through ex gratia payments in Pharmaceutical Manufacturers Assn of Canada v British Columbia (Attorney General) provides an example. ${ }^{80}$ The Court accepted Dicey's definition of the prerogative. It then held that the Crown, like any natural person, was free "to establish programs for public benefit and to define or restrict the distribution of such benefits." $" 81$ The Court added, however, that the Crown's capacity to do so was "subject to the same proviso that limits the exercise of the royal prerogative in its narrow or historical sense: the Crown may not interfere with the "rights, duties or liberties' of its subjects without legal authority." 82 This obiter statement strongly implies that the Crown's inability to interfere with the rights, duties, or liberties of its subjects is the same, whether it is acting under the royal prerogative or under its natural person powers. As phrased, it obfuscates the essential distinction that, whereas the royal prerogative can itself provide the requisite legal authority for such an interference, the Crown's natural person powers cannot. This conflation is less dangerous than one suggesting that the Crown has a residual liberty that, like the prerogative powers, allows the Crown to interfere with its subjects' rights. However, it still distorts the law. On this view, for example, Canadian courts could not recognize the Crown's prerogative power to destroy a subject's property to prevent it from falling into the hands of the enemy in war, subject to payment of compensation, as the House of Lords did in Burmah Oil. ${ }^{83}$

\section{Advantages of Natural Person Powers OVER RESIDUAL LIBERTY}

Notwithstanding the value of Elliott and Harris' distinction between the Crown's positive legal authority under the prerogative and the Crown's residual liberty for drawing attention to the latter's inherent constraints, a natural person powers conception of the Crown's nonprerogative common law powers should be preferred over a residual liberty conception.

First, Elliott and Harris' formulation conflicts with the Supreme Court of Canada's affirmation that "all exercises of public authority must find their source in law." ${ }^{\text {C Contrary }}$ to this principle, they argue that the Crown's residual liberty allows the government to act

Ibid at 228

Ibid at 227-28.

(1997), 149 DLR (4th) 613 (BCCA) at para 27, leave to appeal to SCC refused, 26260 (12 February 1998).

Ibid.

Ibid at para 28 [emphasis added].

Supra note 49.

Dunsmuir, supra note 1 at para 28. 
"without-and without any need of-legal authori[zation]." 85 In contrast, no such inconsistency arises if the Crown is understood to have a discrete head of natural person powers. It may be for this reason that Canadian courts have relied on the concept of the Crown's natural person powers, as opposed to its residual liberty. ${ }^{86}$ Moreover, understanding the Crown's natural person powers as a discrete source of positive legal authority is consistent with the use of express statutory authorization to confer natural person powers on other public authorities, such as municipalities. ${ }^{87}$

Second, the residual liberty conception is misleadingly narrow. It fails to capture the full range of capacities and rights that the Crown shares with natural persons, but which cannot be described as liberties. For example, the Crown's capacity to sue is one of its natural person powers. ${ }^{88}$ It is, however, difficult to conceive of the Crown's right to be recognized by, and have a legal dispute resolved by, the courts as a residual liberty.

Third, the language of residual liberty is undesirably broad. By virtue of its public status, the Crown has the ability to take actions that natural persons cannot take. These include actions the Crown could take without interfering with its subjects' rights or otherwise acting unlawfully. Such actions would fall within a residual liberty of the Crown, but not within a natural person power. Thus, for example, a residual liberty would be broad enough to capture the Crown's ability to enter into treaties, while a natural person power would not be. Yet, the Crown's ability to perform this distinctly public act has not been grounded in broad residual liberty, but in an established historical prerogative power.

Moreover, the Crown's coercive authority may colour its recourse to the general law, such that the analogy with a natural person is no longer tenable. For example, a natural person has no powers to grant regulatory approvals, such as issuing development permits, which could be exploited to bolster its contractual bargaining position and thereby obtain an involuntary benefit from another contracting party. On this basis, the Alberta Court of Appeal found that a municipality with statutory natural person powers had exceeded the scope of those powers when it made the issuance of development permits and subdivision approvals conditional upon developers entering into agreements requiring them to pay fees with respect to off-site facilities and services. According to the Court, "natural person powers do not extend to imposing fees or charges, or coercing developers into agreements to 'voluntarily' pay for infrastructure deficits." 89 Similarly, if the Crown uses its common law natural person powers to extend its coercive authority, it should be found to have acted outside the scope of its authority.

Under a natural person powers conception, the Crown's authority to take actions which it is uniquely competent to take, by virtue of its public status, must be grounded in statute or a prerogative power supported by historical precedent. Under a residual liberties conception, not limited by the analogy to a natural person, the boundaries of uniquely public actions are 
left to the creativity of public officials. Of course, it may not always be easy to draw a sharp distinction between cases where an analogy with a natural person can be sustained and those where it cannot. The availability of public law review for exercises of natural person powers that have a sufficiently public character provides the intermediate response of enhanced judicial scrutiny where the analogy is strained, but not so untenable as to make the action fall outside the scope of the natural person power.

Fourth, a discrete natural person power, together with implied statutory powers and prerogative powers, can provide the government with sufficient authority and flexibility. In carrying out ordinary government business, the Crown's natural person powers authorize a full range of "managerial acts of a kind that any natural person could do, such as making contracts, acquiring or disposing of property, hiring and firing staff and the like." ${ }^{90}$ When pursuing a statutory mandate, the government's implied powers include "all powers which are practically necessary for the accomplishment of the object intended to be secured by the statutory regime." ${ }^{91}$ A broad residual liberty would therefore only be necessary to enable the government to act in a uniquely public manner, and outside the sphere of an existing statutory mandate or historically established prerogative power (for example, treaty-making). Yet, the uniquely public nature of such acts, together with their lack of connection to an existing statutory mandate or prerogative power, suggests that they would likely involve setting novel public policy. Absent an emergency, democratic considerations favour requiring the government to seek statutory authorization (even if framed in very broad terms) to engage in these uniquely public activities that chart a new public policy course, as such authorization enhances opportunities for parliamentary debate and scrutiny. Nor is a broad residual liberty even required in emergencies. Federal, provincial, and territorial statutes already authorize public authorities to take exceptional temporary measures to respond to a wide range of emergencies. ${ }^{92}$ Even if such legislation were not in place, historical precedent very likely supports a prerogative power to take urgent action to protect national security and public order where there is insufficient time to obtain statutory authorization. ${ }^{93}$

In sum, Blackstone's distinction between the Crown's prerogative powers and its natural person powers is essential for determining the existence and scope of the Crown's nonstatutory powers. The Crown's prerogative powers are grounded in historical precedent. Its natural person powers should be determined by an analogy with a natural person, and the

91

$R$ (New London College Ltd) v Home Secretary (SC(E)), [2013] UKSC 51, [2013] 1 WLR 2358 at para 28.

ATCO Gas \& Pipelines Ltd v Alberta (Energy \& Utilities Board), 2006 SCC 4, [2006] 1 SCR 140 at para 51.

See Emergencies Act, RSC 1985, c 22 (4th Supp); Emergency Management and Civil Protection Act, RSO 1990, c E.9; Civil Protection Act, CQLR c S-2.3; Emergency Management Act, SNS 1990, c 8; Emergency Measures Act, RSNB 2011, c 147; Emergency Measures Act, RSPEI 1988, c E-6.1; Emergency Services Act, SNL 2008, c E-9.1; Emergency Program Act, RSBC 1996, c 111; Emergency Management Act, RSA 2000, c E-6.8; The Emergency Planning Act, SS 1989-90, c E-8.1; Emergency Measures Act, CCSM c E80; Civil Emergency Measures Act, RSNWT 1988, c C-9; Emergency Measures Act, SNu 2007, c 10; Civil Emergency Measures Act, RSY 2002, c 34.

The issue has been considered in UK jurisprudence. In Burmah Oil, supra note 49, Lord Pearce referred to the "Crown's prerogative ... to protect its realm and citizens in times of war and peril," but also indicated that the domestic emergency prerogative is more restricted than the war emergency prerogative recognized in that case (ibid at 143-44). A prerogative power to preserve the peace of the realm was recognized in Northumbria Police, supra note 20. While uncontroversial in its application to emergencies (this was not contested), the case has properly been criticized for failing to restrict the prerogative to emergencies, and extending it where statutory authority existed (AW Bradley, "Police Powers and the Prerogative" [1988] Public L 298). 
Crown should not be viewed as having broad residual liberties. The discussion that follows will focus on the Crown's prerogative powers, not its natural person powers. However, to the extent that the exercise of the Crown's natural person powers is subject to public law review, similar principles should ordinarily apply.

\section{JUSTICIABILITY}

\section{A. The Basic Principle: SOURCE OF POWER IS IMMATERIAL}

Since Black, Canadian courts have generally accepted the basic principle that the justiciability of a government action does not depend on the source of power. ${ }^{94}$ In Hupacasath, the Federal Court of Appeal presented this principle as clear and settled: "Whether the question before the Court is justiciable bears no relation to the source of the government power... For some time now, it has been accepted that for the purposes of judicial review there is no principled distinction between legislative sources of power and prerogative sources of power." 95

Considering the concerns that prerogative powers are less consistent with democratic legitimacy and the rule of law than statutory powers, a rule that justiciability does not depend on the source of power is justified. Absent such a rule, government has an incentive to act under the prerogative, rather than under statute, because it can avoid judicial scrutiny by so doing. However, despite broad statements of principle that the source of power does not determine justiciability, Canadian courts have tended to apply peculiar justiciability tests to exercises of prerogative powers.

\section{B. INTEREST-BASED TESTS}

A first category of justiciability tests applied to exercises of prerogative powers is those tests that turn on the nature of the effect of the government action on a person's interests. Among these, a frequently cited test is the requirement that the government action affects a person's rights or legitimate expectations (RLE test). ${ }^{96}$ Canadian jurisprudence almost

Black, supra note 3 at para 47; Black v Advisory Council for the Order of Canada, 2012 FC 1234, 420 FTR 79 at para 48 [Black FC]; Ontario First Nations (2008) Limited Partnership v Aboriginal Affairs (Ontario), 2013 ONSC 7141, 118 OR (3d) 356 at para 37 [OFNLP]; Galati v Johnston, 2015 FC 91, 474 FTR 136 at para 7 [Galati]. While doubts were expressed in Cook, supra note 16 at paras 46, 50, the Supreme Court of British Columbia has since confirmed, in Cape Mudge Indian Band v British Columbia (Ministry of Aboriginal Relations and Reconciliation), 2016 BCSC 556, 2016 BCSC 556 (CanLII), that Cook should not be read as holding that ministerial conduct is not judicially reviewable merely because it flows from a prerogative power, rather than a statutory power (ibid at paras 16-21). The Supreme Court of Canada stated in Hinse, supra note 9, that "it must be borne in mind that the exercise of the royal prerogative, like the exercise of any other statutory power, can be reviewed by the courts" (ibid at para 43). Although dealing with codified prerogative powers ("any other statutory power"), this statement tends to confirm that source of power is irrelevant to justiciability (ibid [emphasis added]). Supra note 33 at para 63 [citation omitted].

See Drabinsky v Advisory Council of the Order of Canada, 2014 FC 21, 445 FTR 240 at para 18 [Drabinsky]; Black FC, supra note 94; Anishinabek, supra note 18 at para 64; OFNLP, supra note 94 at para 48; Chiasson v Canada, 2003 FCA 155, 226 DLR (4th) 351 at para 9. 
exclusively refers to this test in the context of non-statutory powers. ${ }^{97}$ Applying this test, the Court in Black held that the honours prerogative was not justiciable because "[n]o Canadian citizen has a right to an honour" and "no Canadian citizen can have a legitimate expectation of receiving an honour." ${ }^{98}$ However, the RLE test is deficient in several respects. Given the frequency with which the RLE test is invoked, the discussion that follows focuses on the difficulties with that test. As will be seen, however, courts have also articulated interestbased tests in more flexible terms, asking whether "important individual interests are at stake" or whether there are "real adverse consequences for the person affected." 99 Yet, even these more flexible tests suffer from many of the same deficiencies as the RLE test, if to a lesser degree.

\section{INCOMPATIBILITY WITH PROCEDURAL FAIRNESS AND STANDING TESTS}

To begin, the RLE test for justiciability cannot be reconciled with principles governing the duty of fairness. The RLE test imposes a more demanding standard for the impact of a decision on a person than the test for the existence of a duty of fairness. A duty of fairness attaches to any administrative decision "which affects the rights, privileges or interests of an individual." 100 Thus, while effects on a person's privileges or interests are sufficient to trigger a duty of fairness, they are insufficient to render an exercise of prerogative powers justiciable under the RLE test. However, since justiciability is a condition of the procedural fairness inquiry, the interest required to establish justiciability cannot be more demanding than the interest required to give rise to a duty of fairness. If the RLE test were accepted as a general test of justiciability, courts would never reach the procedural fairness inquiry where only a person's interests or privileges were affected. For example, exercises of prerogative powers that harm a person's reputation, an interest typically sufficient to trigger a duty of fairness, but do not affect that person's rights or legitimate expectations, would not be justiciable. ${ }^{101}$ Similarly, the symbolic privileges attached to an appointment to the Order of Canada would be insufficient to render the grant or revocation of such an honour justiciable. ${ }^{102}$

The RLE test of justiciability also conflicts with the law of public interest standing. In Finlay v. Canada (Minister of Finance), a recipient of provincial assistance for persons in need sought to challenge the legality of federal contribution payments to the province as inconsistent with federal cost-sharing legislation. ${ }^{103}$ The Supreme Court of Canada held that Finlay could not establish private interest standing to challenge the federal payments because persons in need only had rights under provincial, not federal, legislation. The federal costsharing payments, therefore, did not affect his rights directly. ${ }^{104}$ The Court nevertheless

One reported case suggests that this test applies to the exercise of statutory powers, but justiciability did not turn on the choice of test (Ontario (Revenue) v Carter, 2010 ONCA 566, 5 CPC (7th) 445 at paras 26-27).

Supra note 3 at paras $60-61$.

Ibid at para 60 .

Cardinal $v$ Director of Kent Institution, [1985] 2 SCR 643 at 653 [Cardinal], cited in Canada (Attorney General) v Mavi, 2011 SCC 30, [2011] 2 SCR 504 at para 38 [Mavi].

Canada (Attorney General) v Canada (Commission of Inquiry on the Blood System), [1997] 3 SCR 440 at para 55 .

Black FC, supra note 94 at para 22.

[1986] 2 SCR 607 at 610 [Finlay].

Ibid at 621-22. 
exercised its discretion to grant Finlay public interest standing to challenge administrative action for exceeding the limits of statutory authority. ${ }^{105}$ The circumstances in Finlay would not satisfy the RLE test. The federal payments did not affect Finlay's rights. The doctrine of legitimate expectations did not apply because there was no government representation about the process or outcome of an administrative decision, and because the doctrine only gives rise to procedural rights, which were not at issue. ${ }^{106}$ At the same time, justiciability was a condition for the Court's recognition of public interest standing. ${ }^{107}$ If an administrative action had to affect a person's rights or legitimate expectations to be justiciable, the Court could not have granted Finlay public interest standing.

\section{INABILITY TO DRAW THE REQUIRED DISTINCTIONS}

Furthermore, the RLE test cannot explain judicial treatment of the justiciability of different prerogative powers. In Black, immediately after confirming that "the basic question in this case" was whether the RLE test was satisfied, the Court gave examples "[t]o put this question in context" that cannot be explained by that test. ${ }^{108}$

By way of example, the Court in Black indicated that "executive decisions to sign a treaty or to declare war" were "matters of "high policy" where "public policy and public interest considerations far outweigh the rights of individuals or their legitimate expectations." ${ }^{109} \mathrm{By}$ stating that individuals' rights and legitimate expectations were outweighed in, rather than absent from, such high policy contexts, the Court implicitly acknowledged that the RLE test would be satisfied. Far from illuminating the RLE test, the Court actually formulated a distinct test: that "high policy" decisions are not justiciable absent a claim under the Canadian Charter of Rights and Freedoms. ${ }^{110}$ The "high policy" test, discussed below, is very different from the RLE test, as Aleksic v. Canada (Attorney General) illustrates. ${ }^{111}$ In that case, the plaintiffs sought to sue the Government of Canada for the injuries and deaths of their relatives, the destruction of their property, and the interruption of their business, all of which they claimed resulted from Canada's participation in the North Atlantic Treaty Organization's missile and aerial bombardment of the Federal Republic of Yugoslavia in 1999. The decision to participate in the bombing was held to be a non-justiciable "high policy" decision. ${ }^{112}$ The idea that the plaintiffs in Aleksic had failed to claim that their rights had been affected is untenable, unless the concept of rights is so internally qualified by policy considerations as to be unworkable as a distinct notion.

As another example to put the RLE test in context, the Court in Black suggested that judicial review ought to be available for certain exercises of the prerogative of mercy. ${ }^{113}$ The Court specifically referred to the Crown's common law prerogative of mercy, preserved by

Baker v Canada (Minister of Citizenship and Immigration), [1999] 2 SCR 817 at para 26 [Baker]. Finlay, supra note 103 at 632.

Supra note 3 at para 52.

Ibid.

Ibid; Canadian Charter of Rights and Freedoms, Part 1 of the Constitution Act, 1982, being Schedule B to the Canada Act 1982 (UK), 1982, c 11 [Charter].

(2002), 215 DLR (4th) 720 (Ont Sup Ct J (Div Ct)) [Aleksic].

Ibid at paras $30-31,36$.

Supra note 3 at paras 53-55.
} 
section 749 of the Criminal Code, as opposed to codified mercy powers. ${ }^{114}$ However, there is no right to a pardon: "[T] he mercy procedure is not the subject of legal rights, as it is initiated only after a convicted person has exhausted his or her rights." "115 Absent specific government representations, it would not affect a person's legitimate expectations either. Indeed, the language of "rights" or "legitimate expectations" cannot explain why exercises of the prerogative of mercy should be justiciable, but exercises of the honours prerogative should not be. Rather, the distinction reflects a value judgment about the importance of the decision to the individual. ${ }^{116}$ It is for this reason that the Court in Black had to explain this distinction by reference to yet another interest-based justiciability test: "The refusal to grant an honour is far removed from the refusal to grant ... a pardon, where important individual interests are at stake. Unlike the refusal of a peerage, the refusal of ... a pardon has real adverse consequences for the person affected." "117

Under this test, justiciability turns on whether the decision affects important individual interests or has real adverse consequences for the person affected. While this test is less formalistic and demanding than the RLE test, it is similarly incompatible with the principles governing the existence of a duty of fairness (as it requires more than a simple effect on a person's interests or privileges) and the availability of public interest standing.

\section{TENDENCY TOWARDS CONSERVATIVE PROCEDURAL REVIEW}

Finally, although Canadian courts have used the "legitimate expectations" portion of the test to expand the range of justiciable exercises of prerogative powers, accessing justiciability through this narrow route has led to conservative and purely procedural review. In Drabinsky, the Federal Court found that a policy outlining the procedure for terminating appointments to the Order of Canada created a legitimate expectation that the prescribed procedure would be followed, making this revocation of an honour justiciable. ${ }^{118}$ Nevertheless, because only legitimate expectations were affected, "the sole basis on which the ... decision [could] be reviewed [was] procedural" and not substantive, because "the doctrine of legitimate expectations relates to procedural fairness, not substantive rights."119 Moreover, the procedural review would consider only the narrow "question [of] whether the process ... met the affected person's legitimate expectations." 120

114 In Hinse, supra note 9, the Supreme Court of Canada considered a claim in civil liability against the federal Crown based on the Minister of Justice's conduct in the exercise of codified mercy powers. Although the Court rejected the claim on the grounds that neither a breach of the applicable standard of conduct nor causation had been established, the decision confirms that such conduct is justiciable.

115 Hinse, ibid at para 65, citing Thatcher $v$ Canada (Attorney General) (TD), [1997] 1 FCR 289 at para 9 (FCTD); see also Diplock LJ in de Freitas v Benny, [1976] AC 239 at 247 (PC).

116 In Smith v Canada (Attorney General) (FC), 2009 FC 228, [2010] 1 FCR 3 [Smith], the Federal Court alluded to this value judgment: "Perhaps in keeping with Canadian sensibilities, Justice Laskin held that the potential grant of a British honour did not engage an important individual interest or give rise to real adverse consequences for Mr. Black" (ibid at para 27).

$117 \quad$ Supra note 3 at para 60.

118 Supra note 96 at para 23, aff'd 2015 FCA 5, 446 NR 375 (refusing to opine on justiciability, but also not questioning the Federal Court's analysis). See also Black FC, supra note 94 at paras 52-66, aff'd 2013 FCA 267, 454 NR 202 [Black FCA] (refusing to opine on "the issues of justiciability and legitimate expectation" (Black FCA, ibid at para 7)).

119 Drabinsky, ibid at para 19 (obiter because only procedural objections had been raised).

120 Ibid. 
However, even though legitimate expectations cannot create substantive rights to a particular outcome, ${ }^{121}$ it does not follow that the sole basis of review should be procedural. Government representations can influence the considerations that the decision-maker must take into account. Thus, a decision may amount to an abuse of discretion if it demonstrated a "singular lack of recognition of the serious consequences [that a] sudden reversal of position inflicted on" the person subject to it. ${ }^{122}$ Also, restricting procedural review to conformity with represented procedures conflicts with the principles governing procedural fairness in the exercise of statutory powers. As discussed below, those principles provide that the content of the duty of fairness is "eminently variable" and must be "decided in the specific context of each case," taking into account an open list of factors, of which legitimate expectations is only one. ${ }^{123}$ Contrary to this flexible and contextual approach, Drabinsky endorses a rigid and conservative procedural fairness inquiry where the Court makes no independent assessment of the requirements of fairness, but simply requires the decisionmaker to comply with its representations as to procedure. ${ }^{124}$

\section{SubJect Matter Tests}

Another category of tests for justiciability of the exercise of prerogative powers is those that exclude from judicial review certain government decisions or actions based on their subject matter. ${ }^{125}$ Subject matter justiciability tests are sometimes articulated broadly to mean that the justiciability of any claim pertaining to the exercise of a prerogative power depends upon the subject matter of the prerogative power itself. On this formulation, each prerogative power can be categorized as either justiciable or non-justiciable. Consistent with this formulation, the Court in Black held that the honours prerogative was not justiciable ${ }^{126}$ and endorsed the following statement from Lord Roskill in CCSU:

Prerogative powers such as those relating to the making of treaties, the defence of the realm, the prerogative of mercy, the grant of honours, the dissolution of Parliament and the appointment of ministers as well as others are not, I think, susceptible to judicial review because their nature and subject matter are such as not to be amenable to the judicial process. ${ }^{127}$

Under a slightly narrower formulation, justiciability depends on the subject matter of the type of decision. For example, decisions to deploy troops ${ }^{128}$ or to participate in a bombing campaign ${ }^{129}$ have been held to be non-justiciable. Such determinations are more limited than Lord Roskill's view that the prerogative power over defence of the realm is not justiciable. Mount Sinai Hospital Center v Quebec (Minister of Health and Social Services), 2001 SCC 41, [2001] 2 SCR 281 at para 63, Binnie J [Mount Sinai].

123 Baker, supra note 106 at para 21.

It does so even though the earlier decision of the Federal Court of Appeal in Black FCA, supra note 118, which refused to opine on the issues of justiciability and legitimate expectations, relied on the Baker factors to conclude that a decision to revoke an honour complied with the requirements of procedural fairness (ibid at para 7).

125 Black, supra note 3 at para 47.

$126 \quad$ Ibid at para 63.

127 Supra note 43 at 418 , cited in ibid at para 58.

128 Blanco, supra note 13 at para 21; Turp 2003, supra note 13 at paras 19-21. 
A significantly narrower formulation provides that justiciability depends upon the subject matter of a particular exercise of a prerogative power. The interest-based tests examined above are amenable to this narrower approach. On such tests, where a particular exercise of the prerogative affects a person's rights, legitimate expectations, or important individual interests, or otherwise has real adverse consequences on a person, it is justiciable. However, exercises of the same prerogative power or decisions of the same type may not be justiciable in other cases. Thus, the Federal Court in Drabinsky could find exercises of the honours prerogative justiciable based on the specific policy in place on the facts, even though the grant or revocation of honours might not be justiciable in other circumstances.

Each of these formulations of the subject matter test carves out a sphere of government action that is immune from judicial review. Applying these tests, once the subject matter of government action is held to be non-justiciable, courts have found that they are not competent to evaluate any challenges to those actions (except, as will be seen, for Charter claims). Thus, in Turp 2003, the applicants argued that Canadian constitutional law requires the executive to obtain parliamentary authorization prior to deploying troops. ${ }^{130}$ The Court declined to decide this question on the basis that deploying troops is a non-justiciable "high policy" decision. ${ }^{131}$ In Black, the Court held that the honours prerogative was not justiciable and therefore, "even if [the Prime Minister's] motives [when exercising the prerogative] were questionable, they [could not] be challenged by judicial review."132

\section{CONTRASTED WITH JUSTICIABILITY OF THE QUESTION TESTS}

In contrast with subject matter justiciability tests, the Supreme Court of Canada has endorsed a test for justiciability that turns on the nature of the question. According to the Supreme Court of Canada in Reference Re Canada Assistance Plan (B.C.), in determining justiciability,

the Court's primary concern is to retain its proper role within the constitutional framework of our democratic form of government.... In considering its appropriate role the Court must determine whether the question is purely political in nature and should, therefore, be determined in another forum or whether it has a sufficient legal component to warrant the intervention of the judicial branch. ${ }^{133}$

In Operation Dismantle v. R., the appellants sought to challenge a Cabinet decision, made under the prerogative, to permit cruise missile testing by the United States in Canadian territory. ${ }^{134}$ They claimed that this decision violated their section 7 Charter right not to be deprived of life, liberty or security of the person except in accordance with the principles of fundamental justice. ${ }^{135}$ Writing for the Court on the issue of justiciability, Justice Wilson focused squarely on the nature of the question being asked:

It might be timely at this point to remind ourselves of the question the Court is being asked to decide.... if the Court were simply being asked to express its opinion on the wisdom of the executive's exercise of its

Supra note 13.

Ibid at paras 8-9, 19-21.

Supra note 3 at para 65.

[1991] 2 SCR 525 at 545 [citations omitted] [emphasis added].

[1985] 1 SCR 441 [Operation Dismantle].

Supra note 110. 
defence powers in this case, the Court would have to decline. It cannot substitute its opinion for that of the executive to whom the decision-making power is given by the Constitution... The question before us is not whether the government's defence policy is sound but whether or not it violates the appellants' rights under s. 7 of the Charter of Rights and Freedoms. This is a totally different question. I do not think there can be any doubt that this is a question for the courts. ${ }^{136}$

Since Operation Dismantle, claims that an exercise of the prerogative violated the Charter have been considered justiciable. ${ }^{137}$ However, Operation Dismantle has often been interpreted as merely establishing a narrow Charter claims exception to non-justiciability. Some decisions suggest that exercises of prerogative powers are only reviewable on Charter grounds, ${ }^{138}$ although this proposition has more recently been rejected. ${ }^{139}$ Other decisions, which remain unassailed, interpret Operation Dismantle as providing a Charter claims exception from the "high policy" subject matter justiciability test. On this test, "apart from Charter claims, [executive decisions on matters of 'high policy'] are not judicially reviewable." ${ }^{140}$ However, this interpretation of Operation Dismantle is untenable. The case should rather be understood as establishing the general principle that justiciability turns on the nature of the question the court is asked to decide, not the subject matter of the government decision or action under review.

Once it is accepted that courts are competent to evaluate Charter claims in highly political spheres of government activity, the subject matter approach is already partly abandoned. There is no principled justification for insisting that courts are incompetent to decide any other questions about highly political government actions. In particular, there is no justification for why courts can answer questions about Charter compliance, but not about compliance with other conditions for the legality of government action.

Indeed, in Finlay, the Supreme Court of Canada relied on Operation Dismantle to conclude that the limits of statutory authority were also justiciable questions. The Supreme Court cited Operation Dismantle for the proposition that "where there is an issue which is appropriate for judicial determination the courts should not decline to determine it on the ground that because of its policy context or implications it is better left for review and determination by the legislative or executive branches of government." ${ }^{141}$ This principle was not restricted to Charter issues, but was deemed "equally applicable to a non-constitutional issue of the limits of statutory authority."142

Returning to Turp 2003 and Black, the Court in each case failed to answer questions that should properly have been held to be justiciable, because it applied a subject matter justiciability test instead of asking whether the particular questions asked were justiciable. In Turp 2003, the Court declined to decide whether Canadian constitutional law requires

Turp 2012, supra note 15 at para 18; Blanco, supra note 13 at para 15.

Hupacasath, supra note 33 at paras 59-61.

Black, supra note 3 at para 52, cited in Aleksic, supra note 111 at paras 29-30 and Turp 2003, supra note 13 at paras $19-21$.

Finlay, supra note 103 at 632 [emphasis added]. Ibid.
} 
Parliament to authorize a troop deployment. ${ }^{143}$ This is a question that courts can competently and appropriately answer, even though the decision to deploy troops is highly political. The Court would not have overstepped its constitutional role by stating that, as a matter of law, no requirement of parliamentary authorization exists. Similarly, if Parliament passed legislation requiring parliamentary authorization for certain military actions, courts could properly decide claims that the legislation had been contravened (unless, correctly construed, the legislation contemplated exclusively non-judicial accountability for non-compliance). ${ }^{144}$ In Black, the Court found that the Prime Minister's exercise of the honours prerogative was not judicially reviewable "even if his motives were questionable." 145 Specifically, the Court would not consider Black's claim that the Prime Minister's action was a "personal intervention" motivated by a "personal vendetta." " However, while courts may be ill-suited to decide who is most worthy of an honour, they are competent to rule on whether a public official has acted in bad faith or for an improper purpose. ${ }^{147}$ As Wade points out, "whether a minister has acted on improper grounds is an issue with which the courts are very familiar" and one which gives rise to "no problem of justiciability." 148 Indeed, in Hinse, the Supreme Court of Canada confirmed that civil liability claims against the Crown based on the Minister of Justice's exercise of codified mercy powers were justiciable, ${ }^{149}$ even though such mercy decisions were "true policy decision[s]" under the applicable legislation. ${ }^{150}$ In deciding the issue of fault, the proper question for the Supreme Court was whether the Minister had acted irrationally or in bad faith (which includes serious recklessness) in exercising the Crown's mercy powers. ${ }^{151}$

What separates Operation Dismantle and Finlay from Turp 2003 and Black is the Court's ability to uphold the rule of law. ${ }^{152}$ The rule of law "provides a shield for individuals from arbitrary state action." 153 An aspect of the rule of law, the principle of legality, requires "that there must be practical and effective ways to challenge the legality of state action." "154 By focusing their justiciability analysis on the nature of the question, the Supreme Court in Operation Dismantle and Finlay concluded that they could answer questions about the conditions of legality of government action: compliance with the Charter and the limits of statutory authority. In contrast, by focusing their justiciability inquiry on the nature of the government decision or action, the Courts in Turp 2003 and Black declined to answer questions about other uncontroversial conditions for the legality of government action: the absence of a constitutional prohibition or bad faith.

Turp 2003, supra note 13 at para 12 .

See e.g. Friends of the Earth $v$ Canada (Minister of the Environment), 2009 FCA 297, 313 DLR (4th)

767, leave to appeal to SCC refused, 33469 (25 March 2010).

Supra note 3 at para 65 .

Ibid at para 39.

Sossin, supra note 55 at $454-55$.

Supra note 45 at 197.

Supra note 9 at para 43.

Ibid at para 4.

Ibid at paras 4, 36, 53.

Sossin, supra note 55 at $454-55$.

Reference re Secession of Quebec, [1998] 2 SCR 217 at para 70 [Secession Reference].

Canada (Attorney General) v Downtown Eastside Sex Workers United Against Violence Society, 2012 SCC 45, [2012] 2 SCR 524 at para 31. 
Subject matter justiciability tests, therefore, tend to prevent courts from fulfilling their rule of law function of supervising the legality of government action. In light of this tendency, the general application of such justiciability tests in prerogative powers cases should be abandoned. The Federal Court of Appeal's 2015 decision in Hupacasath signals a move in this direction. In that case, a First Nation claimed that a foreign investment agreement might affect its Aboriginal rights, and that it therefore had a right to be consulted before the executive brought the agreement into force. ${ }^{155}$ Considering " $[\mathrm{w}]$ hether the question before the Court [was] justiciable," 156 the Court held that, although the "factors underlying a decision to sign a treaty are beyond the courts' ken or capability to assess,"157 the question of whether the First Nation had "enforceable legal rights to be consulted" was justiciable. ${ }^{158}$

\section{A NARROW SPHERE FOR THE CONTINUED APPLiCATION OF A SUBJECT MATTER TEST}

If any spheres of government activity are to be immune from judicial scrutiny, a strong constitutional counterweight to the rule of law principle must be provided. Specifically, the unwritten constitutional principle of democracy may justify the non-justiciability of the exercise of prerogative powers that are integral to the democratic process. ${ }^{159}$ For example, in Galati, the Federal Court held that the Governor General's exercise of the prerogative to grant royal assent to a bill is a legislative act that is not justiciable, even on constitutional grounds. ${ }^{160}$ Similarly, in Guergis, the Ontario Court of Appeal held that the Prime Minister's exercise of the prerogative power to appoint or dismiss Cabinet ministers is not justiciable, identifying no exceptions (only tort claims had been raised). ${ }^{161}$ Although not invoked in these cases, the democratic principle should be understood to require accountability for executive actions integral to the democratic process to be purely political, even when Charter rights are at stake. For example, if a Cabinet minister was dismissed for professing strong religious beliefs that conflicted with the government's policies, it would seem inappropriate for a court to conclude that her dismissal was an unconstitutional interference with her section 2(a) Charter right to freedom of religion. ${ }^{162}$

Judicial supervision of exercises of prerogative powers that are integral to the democratic process is generally inappropriate because such actions more significantly affect the public interest than the interests of particular individuals, and are uniquely visible and subject to parliamentary and public scrutiny, such that democratic accountability provides an adequate alternative remedy to judicial control. ${ }^{163}$ The Supreme Court of Canada reasoned along these

Hupacasath, supra note 33 at paras 1, 33 .

Ibid at para 63 [emphasis added].

Ibid at para 68 .

Ibid at para 69.

Secession Reference, supra note 153 at paras 61-69.

Supra note 94 at para 32.

Supra note 11 at paras $6,86,96$.

Supra note 110.

Based on this argument, I would reject the proposition that, absent a provision for the exercise of the office by deputy, "an incapacity to execute [ministerial offices] with propriety and effect, would form a legal ground of objection" to the appointment of a Cabinet minister (Joseph Chitty Jr, A Treatise on the Law of the Prerogatives of the Crown; and the Relative Duties and Rights of the Subject (London: Butterworth and Son, 1820) at 84, cited in obiter in Askin, supra note 40 at para 38). Instead of entrusting the courts with such capacity determinations, parliamentary and public scrutiny should be viewed as adequate safeguards against ministerial incapacity. If they are not, a democracy is already eroded beyond what the courts could be expected to repair. 
lines in Canada (Auditor General) v. Canada (Minister of Energy, Mines and Resources). ${ }^{164}$ The Supreme Court held that the Auditor General's statutory entitlement to access documents held by Cabinet and a Crown corporation was not justiciable. The existence of adequate alternative remedies was deemed relevant to courts' assessment of "the appropriateness of [their] intervention." 165 The Supreme Court concluded that "a political remedy" was "an adequate alternative remedy" because "[t]he Auditor General [was] acting on Parliament's behalf carrying out a quintessentially Parliamentary function, namely, oversight of executive spending pursuant to Parliamentary appropriations." 166

In Auditor General, the Supreme Court stressed that it was not dealing with a Charter case. ${ }^{167}$ Indeed, political accountability is not generally an adequate alternative remedy for Charter violations because the very purpose of the Charter is to protect individual rights from the political will of the majority. ${ }^{168}$ Nevertheless, the Supreme Court reiterated Justice Wilson's statement in Operation Dismantle that "[i]n the realm of Charter adjudication, s. 1 is 'the uniquely Canadian mechanism through which the courts are to determine the justiciability of particular issues that come before it." 169 Section 1 is the Charter's rights limitation clause. Under section 1, a rights interference will be justified if the government action pursues an important objective and does not disproportionately interfere with the Charter right. ${ }^{170}$ The courts have not explained how this framework applies to a justiciability assessment.

Here, section 1 may allow non-justiciability itself to be justified. The non-justiciability of exercises of prerogative powers that are integral to the democratic process is necessary to preserve that process' integrity, as this prevents judicial interference in its inner workings. While courts can properly review the legality of the outcome of the democratic process, including the constitutionality of legislation and the legality of government actions taken in pursuit of public policies, courts should not interfere with that process and meddle in the very formulation of a majority will. Indeed, justifications of this kind support the constitutional protection of parliamentary privilege. ${ }^{171}$ At the same time, it is difficult to imagine these exercises of prerogative powers seriously interfering with an individual's Charter rights.

Nevertheless, invoking section 1 to determine the justiciability of Charter claims is not without difficulty. Lorne Sossin has argued that section 1 of the Charter is a flawed mechanism for a justiciability inquiry because "a court could only reach the section 1 inquiry if it has already deemed the subject matter suitable for adjudication." ${ }^{\text {"172 }}$ Such a sequential reasoning process may not be essential, however: a court might find that, in light of the strong section 1 justification available, and the absence of an alleged serious rights violation

164 [1989] 2 SCR 49 [Auditor General].

165 Ibid at 92.

166 Ibid at 103 [emphasis added].

167 Ibid at 110.

168 Secession Reference, supra note 153 at para 74.

169 Auditor General, supra note 160 at 91, citing Operation Dismantle, supra note 134 at 491.

Doré v Barreau du Québec, 2012 SCC 12, [2012] 1 SCR 395 at para 7 [Doré]; $R$ v Oakes, [1986] 1 SCR 103 at 139.

171 Canada (House of Commons) v Vaid, 2005 SCC 30, [2005] 1 SCR 667 at paras 41-46 [Vaid]; New Brunswick Broadcasting Co v Nova Scotia (Speaker of the House of Assembly), [1993] 1 SCR 319 at 374-375, 385-390 [New Brunswick Broadcasting].

172 Lorne M Sossin, Boundaries of Judicial Review: The Law of Justiciability in Canada, 2nd ed (Toronto: Carswell, 2012) at 213. 
that could outweigh that justification, it should decline to decide whether a Charter right has been infringed at all. It might also be objected that, since the Charter does not apply to the courts, ${ }^{173}$ section 1 cannot operate to determine whether or not the courts should adjudicate certain matters. However, if section 1 were relied upon to determine the justiciability of Charter claims, the Charter would only be applying to the courts in an incidental way, since such determinations would always occur where the true subject of the proposed litigation is a Charter challenge to government action.

If section 1 does not provide a sound constitutional basis for the non-justiciability of exercises of prerogative powers that are integral to the democratic process, the unwritten constitutional principle of democracy, itself, may offer a more straightforward and cogent basis. Unwritten constitutional principles "assist in the interpretation of the text [of the Constitution] and the delineation of spheres of jurisdiction, the scope of rights and obligations, and the role of our political institutions;" "174 they are also "invested with a powerful normative force, and are binding upon both courts and governments." ${ }^{175}$ Where a particular prerogative power is integral to the democratic process, judicial review would strike at the core of the democratic principle by interfering with the formulation of the democratic will. In this way, insofar as certain prerogative powers, like inherent parliamentary privileges, are "necessary to modern Canadian democracy"176 they may be understood as having constitutional status and thus not subject to judicial challenge on Charter or other constitutional grounds. ${ }^{177}$

The idea that exercises of prerogative powers that are integral to the democratic process should generally be immune from judicial review is grounded in the nature of those actions and their unique suitability to political accountability. In this narrow context, then, justiciability would turn on the subject matter of government action, rather than the question before the court. Even in this narrow context, however, judicial review cannot be categorically excluded. In Conacher, the Federal Court of Appeal found that a statute providing for fixed election dates, when properly construed, neither restricted the Governor General's prerogative power to dissolve Parliament and set an election date, nor the Prime Minister's related advisory authority. ${ }^{178}$ However, had the legislation unequivocally restricted the Governor General's discretion, compliance with such legislation should have been justiciable. ${ }^{179}$ In such a case, considering Parliament's unambiguously expressed intent to impose judicially enforceable constraints on the exercise of a prerogative power integral to the democratic process, the democratic principle itself could no longer support nonjusticiability. Similarly, it should always be open to a party seeking to challenge the exercise of a prerogative power that is integral to the democratic process to demonstrate that political accountability is not an adequate alternative remedy in a particular case. One such instance is where the exercise of the prerogative not only forms part of the democratic process, but also generates a substantive outcome outside the democratic process that directly prejudices

RWDSU v Dolphin Delivery Ltd, [1986] 2 SCR 573 at 600-601 [Dolphin Delivery].

Secession Reference, supra note 153 at para 52.

Ibid at para 54.

New Brunswick Broadcasting, supra note 171 at 387.

Vaid, supra note 171 at para 30; New Brunswick Broadcasting, supra note 171 at 373, 390, 393.

Supra note 12 at paras 5-9.

Assuming it did not contravene section 50 of the Constitution Act, 1867 (UK), 30 \& 31 Vict, c 3, reprinted in RSC 1985, Appendix II, No 5 (but this was a question that Conacher, ibid, did not decide). 
minorities or individuals. ${ }^{180}$ For example, if a federal Cabinet minister were required by statute to personally provide a service to the public, but was unable to do so in both official languages, a challenge to the appointment should be considered justiciable. ${ }^{181}$

\section{Standard Administrative LaW Principles}

In the previous section, I argued that courts should abandon peculiar justiciability tests that have been applied to challenges to exercises of prerogative powers. Partly due to their excessive reliance on such justiciability tests, courts also often fail to apply standard administrative law principles of judicial review to exercises of prerogative powers. As with the application of peculiar justiciability tests, the failure to apply standard administrative law principles to judicial review of exercises of prerogative powers conflicts with the principle that the source of power should not affect judicial review.

It may be objected, however, that principles governing judicial review of statutory powers are ill-adapted to judicial review of non-statutory prerogative powers. Commenting on the House of Lords' holding that prerogative legislation is "subject to review on ordinary principles of legality, rationality and procedural impropriety in the same way as any other executive action," 182 Richard Moules notes: "Usually in judicial review the court ascertains the proper purposes for which a decision maker may act and the relevant considerations he must bear in mind by construing the relevant statute. However, in the case of non-statutory powers such as prerogative powers there is no governing statute to construe." 183 Such concerns are equally relevant in Canada. In this section, I will show how they can be addressed so that standard administrative law judicial review principles can be applied to exercises of prerogative powers. I will further demonstrate that these standard principles allow courts to supervise the legality of exercises of prerogative powers, while also permitting judicial restraint consistent with the appropriate constitutional role of the courts.

In the analysis that follows, I seek to provide a succinct and accurate summary of the administrative law principles that govern judicial review of the exercise of statutory powers, in order to show how these principles can apply to the exercise of prerogative powers. However, as several commentators have lamented, there is considerable doctrinal uncertainty in Canadian administrative law. ${ }^{184}$ It is not the aim of this article to canvass or resolve all of these issues. Rather, I argue that although the principles of Canadian administrative law will require further clarification and refinement, that project should recognize that the same principles can be applied to exercises of statutory and prerogative powers. SCR 1016.

181 See Charter, supra note 110, s 20; Official Languages Act, RSC 1985, c 31 (4th Supp), s 22.

$182 R$ (Bancoult) v Foreign Secretary (No 2) (HL(E)), [2008] UKHL 61, [2009] 1 AC 453 at para 35. Richard Moules, "Judicial Review of Prerogative Orders in Council" (2009) 68:1 Cambridge LJ 14 at 17.

184 See e.g. The Hon Justice David Stratas, "The Canadian Law of Judicial Review: A Plea for Doctrinal Coherence and Consistency" (17 February 2016) [unpublished], online: $<$ ssrn.com/abstract=2733751>; David Mullan, "Unresolved Issues on Standard of Review in Canadian Judicial Review of Administrative Action - The Top Fifteen!" (2013) 42:1 \& 2 Adv Q 1; Paul Daly, "The Scope and Meaning of Reasonableness Review" (2015) 52:4 Alta L Rev 799. 


\section{A. Administrative LaW Judicial Review Principles}

In Canada, there are two basic forms of judicial review of administrative action. ${ }^{185}$ First, under procedural fairness review, courts examine "the manner in which the decision is made"186 for compliance with "prescribed rules of procedure" and "general principles involving the right to answer and defence." 187 Second, through substantive review, courts scrutinize the substance of government actions or decisions to ensure that they do not exceed the government actor's legal authority, applying either a reasonableness or a correctness standard of review. ${ }^{188}$ The suitability of standard administrative law principles of procedural and substantive review to exercises of prerogative powers will be analyzed in turn.

\section{B. Procedural Fairness}

\section{STANDARD PRINCIPLES}

When asked to review a government decision for compliance with the duty of fairness, a court will first determine whether the duty was engaged at all. As discussed above, "[ $\mathrm{t}] \mathrm{he}$ fact that a decision is administrative and affects 'the rights, privileges or interests of an individual' is sufficient to trigger the application of the duty of fairness." 189 Thus, a minimum impact on a person's interests is required for a duty of fairness to exist.

The traditional rule also requires the decision to be administrative. In Canada (A.G.) v. Inuit Tapirisat, the Supreme Court of Canada held that no duty of fairness applies to legislative decisions, that is, polycentric decisions affecting various constituencies and engaging a range of "political, economic and social concerns." 190 Thus, fixing rates for a public utility gave rise to no duty of fairness. ${ }^{191}$ Although Inuit Tapirisat has never been overturned, recent obiter statements in Supreme Court of Canada jurisprudence suggest that it may need to be qualified. In particular, courts may enforce procedures tailored to the legislative decision-making context, such as notice and voting requirements for municipal legislation. ${ }^{192}$ Even the fixing of public utility rates might, today, attract some form of participatory rights. ${ }^{193}$

If a duty of fairness exists, the court will conduct a flexible and contextual inquiry to determine its precise content. ${ }^{194}$ The content of the duty of fairness may include rights to notice, to make written or oral submissions, to be represented by counsel, and to receive reasons for the decision. Procedural fairness also includes the right to an impartial decisionmaker, with the standard of impartiality varying with the administrative context. ${ }^{195}$ In Baker,

Catalyst Paper Corp v North Cowichan (District), 2012 SCC 2, [2012] 1 SCR 5 at para 12 [Catalyst]. Sketchley v Canada (Attorney General) (FCA), 2005 FCA 404, [2006] 3 FCR 392 at para 54.

Dunsmuir, supra note 1 at para 77.

Ibid at paras 47, 50-62.

Baker, supra note 106 at para 20, citing Cardinal, supra note 100 at 653.

[1980] 2 SCR 735 at 755 [Inuit Tapirisat].

Ibid at 754 .

Catalyst, supra note 185 at para 12 .

Canadian National Railway Co v Canada (Attorney General), 2014 SCC 40, [2014] 2 SCR 135 at para 39.

Mavi, supra note 100 at paras 41-42.

Newfoundland Telephone Co v Newfoundland (Board of Commissioners of Public Utilities), [1992] 1
} SCR 623 at 636-39 [Newfoundland Telephone]. 
the Supreme Court of Canada established a non-exhaustive list of five factors for determining the content of the duty of fairness. ${ }^{196}$ The first factor is the nature of the decision: the more closely it "resemble[s] judicial decision making, the more likely it is that procedural protections closer to the trial model will be required." 197 The second is the nature of the statutory scheme and the role of the decision within it (for example, decisions that are final attract greater procedural protections). ${ }^{198}$ The third particularly significant factor is "the importance of the decision to the ... individuals affected," with greater procedural protections applying to more important decisions. ${ }^{199}$ The fourth factor is legitimate expectations. A legitimate expectation that a specific procedure will be followed creates a right to that procedure, while a legitimate expectation about the outcome of a decision gives rise to enhanced procedural protections prior to a contrary decision being made. ${ }^{200}$ Fifth, courts will consider and respect "the choices of procedure made by the agency itself."

The above principles govern the duty of fairness at common law. Nevertheless, absent a violation of the Charter or a quasi-constitutional instrument like the Canadian Bill of Rights, ${ }^{202}$ legislation can displace this duty expressly or by necessary implication. ${ }^{203}$

\section{APPlicability to Prerogative Powers}

As discussed above, standard procedural fairness review principles are often not applied to exercises of prerogative powers. Justiciability tests that require a greater effect on a person's interests than that required to trigger a duty of fairness exclude from judicial review decisions that would otherwise attract a duty of fairness. Moreover, the emphasis on legitimate expectations as the gateway for justiciability has resulted in this single factor, as it relates to representations about specific procedures, dominating the inquiry into the content of the duty of fairness. However, standard procedural fairness principles are suited to judicial review of exercises of prerogative powers.

Once interest-based justiciability tests are abandoned, standard procedural fairness principles provide that the existence of a duty of fairness depends on an effect on a person's rights, privileges, or interests. This test avoids the difficulties of drawing categorical distinctions between such highly discretionary decisions as the conferral of honours and the granting of pardons using the language of rights. The language of rights is unhelpful because there is a sense in which no person has the right to have a highly discretionary power exercised in one way or another. Under standard procedural fairness principles, a duty of fairness will exist in both such individualized decision-making contexts. Distinctions between the two can then be drawn through the contextual inquiry into the content of the duty.

\footnotetext{
$196 \quad$ Supra note 106 at para 28.

$197 \quad$ Ibid at para 23.

Ibid at para 24.

Ibid at para 25 .

Ibid at para 26 .

Ibid at para 27.

SC 1960, c 44, ss 1(a), 2(e).

Ocean Port Hotel Ltd v British Columbia (General Manager, Liquor Control and Licensing Branch),
} 2001 SCC 52, [2001] 2 SCR 781 at para 22. 
The standard principles of procedural fairness review flexibly accommodate a wide range of decision-making contexts. They apply to the "spectrum of administrative bodies whose functions vary from being almost purely adjudicative to being political or policy-making in nature. ${ }^{204}$ In Baker, these principles were applied to a minister's broad statutory discretion to exempt a person from statutory immigration conditions on humanitarian and compassionate grounds. ${ }^{205}$ This discretion codified an aspect of the prerogative to determine who may enter and remain in Canada. ${ }^{206} \mathrm{~A}$ person requesting humanitarian and compassionate relief does "not ... attempt to assert a right, but, rather, attempts to obtain a discretionary privilege." ${ }^{207}$ It follows that standard procedural fairness review should be available for similarly broad discretionary powers under prerogative powers that have not been codified.

Furthermore, although the Baker factors refer to the statutory scheme, "[t]he simple overarching requirement is fairness, and this 'central' notion of the 'just exercise of power' should not be diluted or obscured by jurisprudential lists developed to be helpful but not exhaustive." 208 Thus, the specific wording of the factors need not be a straitjacket confining the procedural fairness inquiry, but can be adapted to the prerogative powers context. Based on how those factors were applied in Baker, the necessary adaptation would be minor. In that case, the humanitarian and compassionate relief decision was found to be (1) "very different from a judicial decision, since it involve[d] the exercise of considerable discretion and require [d] the consideration of multiple factors"; (2) "an exception to the general principles" under the statutory scheme; (3) particularly important to the claimant; (4) not the subject of any legitimate expectations; and (5) governed by procedures that the Minister had "considerable flexibility" under the statute to establish. ${ }^{209}$ The first two factors weighed against extensive procedural protections, the third weighed in favour, the fourth was neutral, and the fifth supported deference to the Minister's selected procedures. ${ }^{210}$ Very similar considerations would likely apply to the exercise of certain prerogative powers, and the analogy with the Crown's residual uncodified mercy powers is particularly apt. ${ }^{211}$ Only the second and the fifth factors refer to the statutory scheme. However, even without a statute, the substance of the second factor can be considered, that is, whether the decision involves an exceptional discretionary privilege or a widely available administrative practice. Based on this factor, decisions to grant an honour or a pardon could be distinguished from decisions to issue a passport. Similarly, the fifth factor would simply require deference to the procedures selected by the government for exercising the prerogative.

Perhaps the best reason for applying standard procedural fairness principles to exercises of prerogative powers is the emphasis those principles place on the importance of the decision to the individual affected. This factor is lost if courts restrict their fairness assessment to requiring the government to comply with those procedures that a person could

Newfoundland Telephone, supra note 195 at 637.

Supra note 106 at paras $1,29,31$.

Tuel v Canada (Minister of Citizenship and Immigration), 2011 FC 223, 2011 FC 223 (CanLII) at para

1 [Tuel]; Grillas $v$ Canada (Minister of Manpower and Immigration), [1972] SCR 577 at 581.

Canada (Citizenship and Immigration) v Khosa, 2009 SCC 12, [2009] 1 SCR 339 at para 57 [Khosa], citing Prata v Canada (Minister of Manpower and Immigration), [1976] 1 SCR 376 at 380.

Mavi, supra note 100 at para 42 [emphasis in original].

Baker, supra note 106 at para 31 .

Ibid.

Criminal Code, supra note 9, s 749. 
legitimately expect. Moreover, the importance of the decision provides a compelling justification for varying levels of judicial intervention. For example, it supports the distinction the Court in Black wished to draw, but failed to adequately justify, between the conferral of honours and pardons. In Smith, the Federal Court stressed the importance of the decision to the individual when it imposed substantial procedural requirements on the Government of Canada's decision to withdraw clemency support for a Canadian citizen on death row in the US. ${ }^{212}$ The Court explained that:

In the realm of diplomatic assistance to citizens in legal trouble in foreign jurisdictions everything pales in significance to the cause of one's imminent execution and the corresponding interest in avoiding it. One would expect, therefore, that any decision by the Canadian government to withdraw clemency support for a person in such a predicament would also attract the most rigorous and anxious scrutiny by the decision maker and, where that is not evident, by the supervising court. ${ }^{213}$

In concluding that Smith was entitled to "full consultation," "fair and objective consideration" of his circumstances, and reasons for the Government's reversal of position, the Court focused on his legitimate expectations rather than on a full assessment of the Baker factors. ${ }^{214}$ However, it would be artificial to conclude that the importance of the decision to Smith had not influenced the Court's imposition of significant procedural protections.

Finally, standard procedural fairness review principles will not lead to excessive judicial interference in exercises of prerogative powers. Legislative decisions either do not give rise to duties of fairness, following Inuit Tapirisat, or only give rise to procedural requirements adapted to their policy context. In many instances, exercises of prerogative powers over foreign affairs (for example, treaty-making) and defence (for example, deciding to participate in a military campaign) would fall under the Inuit Tapirisat exclusion. Moreover, unlike a municipality's democratic processes, there are arguably no formal participatory procedures adapted to these policy contexts. Although the standard principles apply a low threshold for the existence of a duty of fairness, the factors relevant to determining the content of the duty allow for minimal procedural guarantees. For example, absent legitimate expectations, it is unlikely that the conferral of honours would attract procedural duties beyond the existence of a rational and impartial process for candidates to be identified and considered. Furthermore, the fifth Baker factor requires deference to the government's procedures for exercising prerogative powers. In addition to these various devices of judicial restraint, absent constitutional or quasi-constitutional constraints, it is also always open to the legislature to immunize certain exercises of prerogative powers from procedural fairness review, and face the political consequences of such legislation. 


\section{Substantive RevieW}

\section{STANDARD PRINCIPLES}

Apart from procedural illegality, principles of substantive review of administrative action provide that a government actor will exceed its jurisdiction by deciding a matter unreasonably or, in those cases where it is required to decide correctly, by deciding incorrectly. ${ }^{215}$ Canadian courts have rejected approaches to substantive review that require a court to "identify a categorical or nominate error, such as bad faith, error on collateral or preliminary matters, ulterior or improper purpose, no evidence, or the consideration of an irrelevant factor." ${ }^{216}$ Instead, courts apply the standard of review analysis to determine whether a particular administrative decision is reviewable on a correctness or a reasonableness standard. An administrative decision that does not stand up to judicial scrutiny on the applicable standard of review will be unlawful. In this way, the standard of review analysis provides "an overarching or unifying theory for review of the substantive decisions of all manner of statutory and prerogative decision makers." 217

\section{a. Selecting the Standard of Review}

To determine the applicable standard of review, courts first "ascertain whether the jurisprudence has already determined in a satisfactory manner the degree of deference to be accorded with regard to a particular category of question." ${ }^{218}$ The recognized categories can be summarized as follows:

\footnotetext{
The standard of correctness governs: (1) a constitutional issue; (2) a question of "general law "that is both of central importance to the legal system as a whole and outside the adjudicator's specialized area of expertise""...; (3) the drawing of jurisdictional lines between two or more competing specialized tribunals; and (4) a "true question of jurisdiction or vires" ... reasonableness is normally the governing standard where the question: (1) relates to the interpretation of the tribunal's enabling (or "home") statute or "statutes closely connected to its function, with which it will have particular familiarity"...; (2) raises issues of fact, discretion or policy; or (3) involves inextricably intertwined legal and factual issues. ${ }^{219}$
}

Where this initial "inquiry proves unfruitful,",220 courts determine the standard of review based on the following factors: "(1) the presence or absence of a privative clause; (2) the purpose of the tribunal as determined by interpretation of enabling legislation; (3) the nature of the question at issue, and; (4) the expertise of the tribunal." 221

(following Dunsmuir, supra note 1 , the Court's reference to patent unreasonableness can be updated to refer to reasonableness); Catalyst, supra note 185 at para 12 .

Dr Q v College of Physicians and Surgeons of British Columbia, 2003 SCC 19, [2003] 1 SCR 226 at para $22[D r Q]$. See also Bibeault, ibid at 1088 .

Dr Q, ibid at para 25, citing David J Mullan, Administrative Law (Toronto: Irwin Law, 2001) at 108. These comments referred to the predecessor of the current standard of review analysis, the "pragmatic and functional approach," but they are equally applicable to both.

Dunsmuir, supra note 1 at para 62.

Smith v Alliance Pipeline Ltd, 2011 SCC 7, [2011] 1 SCR 160 at para 26 [citations omitted] [Alliance].

Dunsmuir, supra note 1 at para 62.

Ibid at para 64 . 


\section{b. Applying the Standard of Review}

A court applying the correctness standard engages in its own assessment of the matter under review, and does "not show deference to the decision [maker]."222 If the court does not agree with the administrative decision, it "will substitute its own view and provide the correct answer.",223

In contrast, when applying the reasonableness standard, "courts cannot substitute their own appreciation of the appropriate solution, but must rather determine if the outcome falls within 'a range of possible, acceptable outcomes which are defensible in respect of the facts and law." 224 Thus, "[r] easonableness is a deferential standard animated by the principle that ... certain questions that come before administrative tribunals do not lend themselves to one specific, particular result.,"225

The reasonableness standard applies to a wide range of administrative decisions, from an adjudicator's interpretation of his constituent statute, ${ }^{226}$ to a minister's discretionary decision not to relieve a person from a finding of inadmissibility to Canada based on an evaluation of the "national interest," 227 to a municipal council's exercise of "a broad and virtually unfettered legislative discretion to establish property tax rates." 228 As such, what reasonableness requires "must be assessed in the context of the particular type of decision making involved." 229 Thus, "[r] easonableness is a single standard that takes its colour from the context." 230 In some circumstances, there will be a wide range of reasonable decisions available to the decision-maker; in others, the range of reasonable decisions will be significantly constrained. Indeed, in the realm of statutory interpretation there will be cases "[w] here the ordinary tools of statutory interpretation lead to a single reasonable interpretation." 231

Moreover, because fully articulated reasons for administrative actions or decisions will not always be available, courts can "consider the reasons that could be offered for the decision when conducting a reasonableness review." ${ }^{232}$ Courts therefore determine the reasonableness of a government decision through an "organic" evaluation of the reasons, together with the outcome, seeking to supplement reasons that appear incomplete before seeking to subvert them. ${ }^{233}$

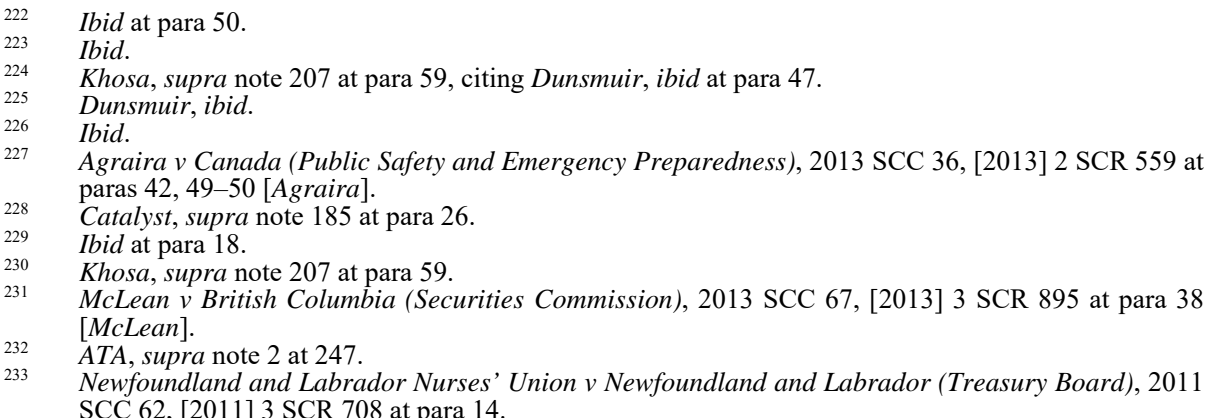




\section{APPlicability to Prerogative Powers}

Applying current substantive review principles, the vast majority of exercises of prerogative powers will be reviewable on a reasonableness standard, since they will raise issues of fact, discretion or policy. The central inquiry is, therefore, whether judicial deference under a reasonableness standard provides an adequate mechanism for reviewing exercises of prerogative powers.

\section{a. Judicial Indications of a Need for Deference}

The difficulties associated with peculiar justiciability tests are fully discussed above. Beyond these, tenuous judicial qualifications of justiciability show that courts require the resources of deference to deal with prerogative cases. In attempting to manage peculiar justiciability tests, courts have asserted that prerogative powers lie on a "spectrum of judicial reviewability" 234 or a "justiciability continuum." 235 However, the concept of a justiciability spectrum or continuum is not coherent. If a matter is justiciable, the court will consider it; if not, the court will not consider it. Justiciability is an all or nothing proposition. In contrast, the variable judicial restraint that courts have sought to invoke is the essence of deference under a contextual reasonableness standard.

\section{b. Judicial Review of Discretionary Statutory Powers and Codified Prerogative Powers}

Canadian courts routinely apply reasonableness review to discretionary powers with a statutory source, including pure statutory creations and codifications of prerogative powers. Reasonableness review has been applied to polycentric policy decisions and to individualized decisions to grant exceptional discretionary privileges. For example, Canadian courts have applied the reasonableness standard to:

(1) The Canadian Radio-television and Telecommunications Commission's (CRTC) broad statutory discretion to determine just and reasonable rates for telecommunications services; ${ }^{236}$

(2) a municipality's "broad and virtually unfettered legislative discretion to establish property tax rates;",237

(3) codifications of the prerogative power to grant an inadmissible person a discretionary privilege to remain in Canada, based on "humanitarian and compassionate considerations" 238 or an assessment of the "national interest;",239 and 
(4) the Minister of Justice's "highly discretionary" powers, "derive[d] from the Royal Prerogative of Mercy," to grant the "extraordinary remedy" of a fresh hearing of a criminal matter ${ }^{240}$ if he "is satisfied that there is a reasonable basis to conclude that a miscarriage of justice likely occurred," 241 "tak[ing] into account all matters that the Minister considers relevant." 242

The application of reasonableness review to highly discretionary statutory powers arguably supports its application to similarly discretionary non-statutory prerogative powers. However, the challenges identified by Moules are potentially most acute in the context of substantive review. Absent a statutory framework, a court may struggle to articulate an objective legal basis for why the exercise of a discretionary power was unreasonable. In this context, a court may be concerned that reasonableness review will necessarily amount to improperly questioning the wisdom of policy determinations. ${ }^{243}$ Indeed, "[t]he statute and regulations define the scope of the discretion and the principles governing the exercise of the discretion, and they make it possible to determine whether it has in fact been exercised reasonably." 244

Thus, in exercising its rate-setting discretion, the CRTC was required to consider policy objectives articulated in its enabling legislation. ${ }^{245}$ The Court could then assess the reasonableness of the CRTC's discretionary decision against those policy objectives. ${ }^{246}$ Even the mere articulation of the discretion in the statute can provide objective constraints on its scope. A discretion to grant an extraordinary remedy for a "miscarriage of justice," based on "humanitarian and compassionate considerations," or based on an assessment of the "national interest," however broad, is still confined by the types of considerations that can reasonably be captured by each of those expressions.

However, the Supreme Court of Canada's application of reasonableness review to a municipal property tax bylaw, in Catalyst, indicates that reasonableness review is possible even where statutory discretion is "broad and virtually unfettered." ${ }^{247}$ Municipal councillors had "extensive latitude in what factors they [were free to] consider," from "objective factors directly relating to consumption of services" to "broader social, economic and political factors that [were] relevant to the electorate." ${ }^{248}$ They were also "not required to give formal reasons or lay out a rational basis for bylaws." 249 Nevertheless, the Supreme Court made it clear that " $\mathrm{t}]$ he fact that wide deference is owed to municipal councils does not mean that they have carte blanche." 250 The bylaw would not survive reasonableness review if it was "manifestly unjust," "disclosed bad faith," "involved such oppressive or gratuitous interference with the rights of those subject to [it]" as to exceed any reasonable

Ross $v$ Canada (Minister of Justice), 2014 FC 338, 453 FTR 56 at para 32. See also Hinse, supra note 9 at paras $28,30-34,43$.

Criminal Code, supra note 9, s 696.3(3)(a).

Ibid, s 696.4.

Fontaine v Canada (Attorney General), 2017 FC 431, 2017 FC 431 (CanLII) at paras 39-41, 47.

Montréal (City) v Montreal Port Authority, 2010 SCC 14, [2010] 1 SCR 427 at para 33.

Bell, supra note 236 at paras 28,36 .

Ibid at paras $74-76$.

Supra note 185 at para 26.

Ibid at para 30 .

Ibid at para 33.

Ibid at para 24. 
justification, ${ }^{251}$ or had been adopted for "improper motives." ${ }^{252}$ Reasonableness review, in this sense, does not depend on constraints imposed by the statutory scheme, and should therefore be equally available for exercises of non-statutory prerogative powers.

c. Defects in the Nature of Bad Faith:

Substantive or Jurisdictional Review?

Catalyst confirms that courts are competent to review government actions for bad faith, improper purpose, manifest injustice, or oppressive or gratuitous infliction of prejudice in excess of any reasonable justification, even in the absence of statutory constraints on government discretion. Indeed, bad faith, improper purpose, and flagrant impropriety are accepted grounds for judicial review of the exercise of prosecutorial discretion, which derives from the prerogative. ${ }^{253}$ These grounds are available whether the specific aspect of prosecutorial discretion is codified (for example, the discretion to stay a criminal proceeding) ) $^{254}$ or remains entirely non-statutory (for example, the discretion to decide whether to bring the prosecution of a charge laid by police). ${ }^{255}$

More broadly, judicial review for defects in the nature of bad faith is justified on the basis that those minimal constraints on executive discretion are inherent in the public nature of prerogative powers. The essentially public character of the prerogative is a principle of long standing. In 1883, Chief Justice Ritchie wrote in R. v. McLeod that the "prerogatives of the Crown must not be treated as personal to the sovereign; they are great constitutional rights, conferred on the sovereign, upon principles of public policy, for the benefit of the people, and not, as it is said, 'for the private gratification of the sovereign." ${ }^{256}$ These propositions follow John Locke's understanding of the prerogative as the "power to act according to discretion, for the public good, without the prescription of the law, and sometimes even against it.,"257

Catalyst's more novel suggestion is that review on these limited grounds is simply the application of a contextual reasonableness standard in circumstances where the only judicially cognizable constraint on government power is that it is public in nature. However, applying reasonableness review in this sense to exercises of prerogative powers is controversial. The Supreme Court of Canada expressly rejected judicial scrutiny of the exercise of prosecutorial discretion for its reasonableness in Nixon. According to the Supreme Court, reasonableness review would amount to "second-guessing the decision," which would undermine the independence and impartiality of the Attorney General. ${ }^{258}$ Sharply distinguishing substantive administrative review from review for defects in the nature of bad faith, the Supreme Court held that "the court does not assess the reasonableness or correctness of the decision itself; it only looks behind the decision for "proof of the

Ibid at para 21, citing Kruse v Johnson, [1898] 2 QB 91 at 99.

Catalyst, ibid at para 28.

Krieger, supra note 10 at paras 24, 49, 51; $R$ v Nixon, 2011 SCC 34, [2011] 2 SCR 566 at para 59 [Nixon].

Criminal Code, supra note 9, s 579.

Krieger, supra note 10 at para 46.

(1883), 8 SCR 1 at 26, cited in Lordon, supra note 20 at 61.

John Locke, Two Treatises of Government (Dublin: Sarah Cotter and J Sheppard, 1766) at 271, relied upon by Lord Denning in Laker Airways Ltd v Department of Trade, [1977] 1 QB 643 at 705 (CA). Nixon, supra note 253 at para 52. 
requisite prosecutorial misconduct, improper motive or bad faith in the approach, circumstances or ultimate decision." ${ }^{259}$

Under Catalyst, judicial review for defects in the nature of bad faith is simply an application of the minimum content of the reasonableness standard, whereas under Nixon, it is categorically distinct from reasonableness review. A possible rationale for Nixon's categorical distinction may lie in the traditional rule that courts are entitled to determine the scope of a prerogative power, but not to review its exercise. ${ }^{260}$ In this way, the traditional rule categorically distinguished jurisdictional review from substantive review of the exercise of prerogative powers. Viewed through this prism, Nixon's categorical distinction may rest upon an understanding of defects in the nature of bad faith as jurisdictional rather than substantive. Such defects would be jurisdictional because actions taken in bad faith by public officials are always outside the scope of their authority.

This explanation of Nixon, however, is at odds with contemporary administrative law principles. Jurisdictional review cannot be contrasted with substantive review because it is precisely by acting in a manner that does not withstand scrutiny on the applicable standard of substantive review that a government actor exceeds its jurisdiction. In this sense, unreasonableness is, itself, a jurisdictional defect. ${ }^{261}$ Moreover, nominate grounds of review have been rejected in favour of an overarching framework for substantive review of decisions based on the standard of review analysis. ${ }^{262}$ Traditionally, administrative law categorically distinguished discretionary decisions from questions of law, such that "decisions classified as discretionary [could] only be reviewed on limited grounds such as ... bad faith ... improper purpose, and ... irrelevant considerations." 263 However, recognizing that "a rigid dichotomy of 'discretionary' or 'non-discretionary' decisions" 264 could not be sustained, the Supreme Court of Canada held in Baker that discretionary decisions should be approached under the same substantive review framework as questions of law. ${ }^{265}$ To maintain defects in the nature of bad faith as a form of review categorically distinct from reasonableness review in the context of prerogative powers would be to maintain a distinction the Supreme Court has already found untenable in the context of statutory discretionary powers. It would also perpetuate divergent approaches to judicial review of the exercise of statutory as opposed to prerogative powers, despite the jurisprudential consensus that there is no principled basis for such a distinction.

More fundamentally, this rationale for Nixon creates an unnecessary rule of law problem. The Supreme Court of Canada's decision in Dunsmuir established that "[i]t is ... inconsistent with the rule of law to retain an irrational decision."266 The Court replaced the prior two standards of patent unreasonableness and reasonableness simpliciter with a single

Ibid.

Black, supra note 3 at paras 26, 29, 45 .

A jurisdictional defect in this sense must be distinguished from the category of "true questions of jurisdiction or vires" to which the correctness standard of review in principle applies, but the very existence of which is doubtful since the Supreme Court of Canada's decision in ATA, supra note 2 at paras 30-44.

$\operatorname{Dr} Q$, supra note 216 at para 22; Bibeault, supra note 215 at 1088.

Baker, supra note 106 at para 53.

Ibid at para 54.

Ibid at paras 54-56.

Supra note 1 at para 42. 
reasonableness standard, holding that "it would be unpalatable to require parties to accept an irrational decision simply because ... the irrationality of the decision is not clear enough." ${ }^{267}$ Thus, government action must be reasonable if it is to be lawful. Nixon suggests that courts must allow an unreasonable government action to stand, thereby offending the rule of law. In contrast, Catalyst gives rise to no such difficulty. It does not permit an unreasonable decision to stand, but rather explains what reasonableness means where the constraints on discretionary power do not derive from the words of the statute, but from the public nature of the power.

Furthermore, the Supreme Court of Canada's recent decision in Hinse points towards a better explanation of Nixon. Specifically, judicial review of the exercise of prosecutorial discretion may simply be a special case requiring an exceptional level of deference from the courts. According to the Supreme Court, the constitutionally entrenched independence of the prosecutor's office justifies an exceptionally high fault threshold in an action for malicious prosecution. ${ }^{268}$ It is "fundamental to the integrity and efficiency of the criminal justice system" that prosecutors "be able to act independently of any political pressure from the government" and "be beyond the reach of judicial review, except in cases of abuse of process. ${ }^{269}$ In contrast, in making a mercy decision (as with the exercise of most prerogative powers), "the Minister must weigh social, political and economic factors in making his or her decision." 270 Therefore, "an action for malicious prosecution must be based on malice or on an improper purpose," 271 whereas an action against the Crown based on the Minister of Justice's exercise of codified mercy powers can be based on mere bad faith, including serious recklessness. ${ }^{272}$ Viewed in light of Hinse, Nixon should be read as holding that the constitutionally entrenched independence of the prosecutor's office displaces the ordinary principles of judicial review. Prosecutorial independence thus provides its own exceptional rule of law justification for courts to allow an irrational decision to stand, and to require more before they interfere. For this reason, Nixon should not preclude judicial review of other prerogative powers on a reasonableness standard, applying the principles in Catalyst, absent a similar constitutional justification.

\section{d. $\quad$ Charter and Reasonableness Review}

Recent jurisprudential developments on Charter review of administrative action also support the application of standard substantive review principles to exercises of prerogative powers. Since Operation Dismantle, courts have consistently held that exercises of prerogative powers are judicially reviewable on Charter grounds. However, in Doré, the Supreme Court of Canada eschewed a sharp distinction between Charter and administrative law review, holding that courts should assess Charter challenges to administrative decisions under the framework of substantive administrative law review. ${ }^{273}$ Specifically, courts should apply a reasonableness standard to "determine whether an administrative decision-maker has

Ibid [emphasis in original].

Hinse, supra note 9 at paras 40-41.

Ibid at para 40.

Ibid at para 42 .

Ibid at para 40 .

Ibid at paras 48-53.

Supra note 170. 
taken sufficient account of Charter values in making a discretionary decision." ${ }^{274}$ The Supreme Court further held that "administrative decisions are always required to consider fundamental values" and, as such, "administrative bodies are ... required ... to consider Charter values within their scope of expertise." $" 275$

After Doré, the established rule allowing Charter review of exercises of prerogative powers entails reasonableness review when Charter claims are raised. An administrative decision that "does not take Charter rights into account or that restricts them disproportionately [is] an unreasonable decision." ${ }^{276}$ Indeed, in El Shurafa v. Canada (Attorney General), the Federal Court followed Doré in a case involving the prerogative power over passports. ${ }^{277}$ Under the rubric of reasonableness review, the Court held that an exercise of the prerogative power to issue a geographically limited passport constituted a justified interference with the applicant's Charter mobility rights. ${ }^{278}$

More significantly, Doré's affirmation that administrative decision-makers must always consider Charter values implies that reasonableness review informed by Charter values cannot be restricted to cases where it is specifically alleged that an exercise of a prerogative power infringed a Charter right. Like the requirement of good faith, Charter values are therefore a constraint on the exercise of discretionary power, even in the absence of a statutory framework. As such, Doré extends the established rule of judicial review of prerogative powers on Charter grounds to a general rule of reasonableness review guided by Charter values.

\section{e. Judicial Restraint in Charter Cases}

Doré confirmed that section 1 of the Charter entails deference in the course of Charter review of discretionary administrative decisions. ${ }^{279}$ Beyond deference to the substantive decision, seminal decisions on Charter review of exercises of prerogative powers invoke other devices of judicial restraint that can similarly mitigate concerns about excessive judicial intervention through substantive review on a reasonableness standard.

In Operation Dismantle, the claim was ultimately held to be non-justiciable because the alleged harm from Canada permitting the US to carry out cruise missile testing was "too uncertain, speculative and hypothetical to sustain a cause of action." ${ }^{280}$ In Khadr, the Supreme Court concluded that Canada's interrogation of a youth detained at Guantanamo Bay, in circumstances where he had no access to counsel, where he had been subjected to scheduled sleep deprivation, and where his statements would be used against him in US criminal proceedings, violated his section 7 Charter rights. ${ }^{281}$ However, in order to give due weight to the executive's constitutional responsibility for complex foreign affairs decisions, the Supreme Court held that "the proper remedy [was] to grant Mr. Khadr a declaration that

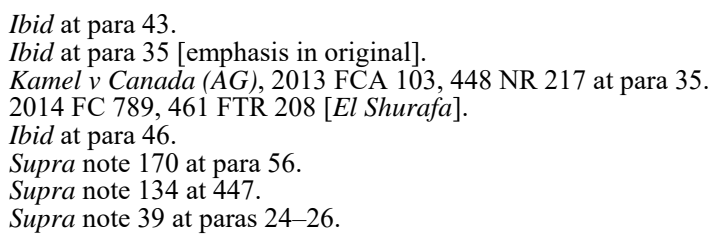


his Charter rights [had] been infringed, while leaving the government a measure of discretion in deciding how best to respond. $" 282$

These Charter cases show that, even if standard administrative law principles are applied to exercises of prerogative powers, courts have mechanisms beyond deference allowing them to limit their intervention. These include grounds of non-justiciability not peculiar to the prerogative powers context and the broad discretion inherent to prerogative remedies ${ }^{283}$ and declarations. ${ }^{284}$

\section{f. Reasonableness Review: A Continuum of \\ Constraints on the Exercise of Prerogative Powers}

Applying a contextual reasonableness standard to exercises of prerogative powers recognizes that the limits on discretionary authority lie along a continuum. Various contextual factors will determine the contours of discretionary powers in particular cases. The contextual reasonableness standard allows courts to calibrate judicial review to the variable constraints on administrative discretion.

Following Baker, "discretion must be exercised in accordance with ... the principles of the rule of law, the principles of administrative law, the fundamental values of Canadian society, and the principles of the Charter." 285 Some of these constraints on discretionary powers have already been discussed, including requirements of non-arbitrariness, good faith, and respect for Charter values. Exercising discretion in accordance with Charter values requires not only proportionate justifications for interferences with Charter rights, as Doré

Ibid at para 2 .

ATA, supra note 2 at para 22 .

Solosky $v R,[1980] 1$ SCR 821 at 830 . However, in some jurisdictions, statutes governing judicial review procedure may complicate the granting of declarations in applications for judicial review of the exercise of prerogative powers. These statutes were designed to simplify proceedings challenging the legality of government action, by establishing a unified procedure for the prerogative remedies of mandamus, certiorari, and prohibition (previously available on application) and the remedies of a declaration and an injunction (previously available in an action) (see Judicial Review Act, RSPEI 1988, c J-3, s 2(1)(a)). For example, section 2(1) of Ontario's Judicial Review Procedure Act, RSO 1990, c J.1 [JRPA], provides:

On an application by way of originating notice, which may be styled "Notice of Application for Judicial Review", the court may, despite any right of appeal, by order grant any relief that the applicant would be entitled to in any one or more of the following:

1. Proceedings by way of application for an order in the nature of mandamus, prohibition or certiorari.

2. Proceedings by way of an action for a declaration or for an injunction, or both, in relation to the exercise, refusal to exercise or proposed or purported exercise of a statutory power.

Such legislation is procedural only, and does not change the substantive law (Cook, supra note 16 at para 50). As such, remedies in the nature of mandamus, certiorari, and prohibition can evolve with the common law, such that they are now available with respect to exercises of prerogative powers. However, the drafting of provisions like section 2(1) in Ontario's JRPA (ibid; see also Judicial Review Procedure Act, RSBC 1996, c 241, s 2), suggests that declarations and injunctions are only available on an application for judicial review in relation to the exercise, refusal to exercise, or proposed or purported exercise of a statutory power, making it necessary to bring an action to claim these remedies in relation to exercises of prerogative powers. Due to the similarity of mandamus and prohibition to injunctions, the primary difficulty is with respect to declarations. Considering courts' broad jurisdiction to grant declarations, the flexibility of this remedy, and the purpose of judicial review procedure legislation to simplify proceedings, courts should seek to avoid the above interpretation where the statutory language allows. Where it does not, they should avail themselves of other procedural devices (for example, the power to convert an application into an action with respect to an issue to be tried in Ontario (Rules of Civil Procedure, RRO 1990, Reg 194, s 38.10(3))) in order to grant the most appropriate remedy with the least procedural encumbrance. 
directs, but also regard for the more open-textured values that the Charter expresses, such as "equality, autonomy, liberty, privacy and human dignity."286 Additionally, Canada's international obligations, especially international human rights norms, can be used to identify the fundamental values of Canadian society, which constrain the exercise of discretion. ${ }^{287}$

Government representations about how discretion will be exercised are also relevant. Actions that renege on such representations will be an abuse of discretion, and therefore unreasonable, when they demonstrate a "singular lack of recognition of the serious consequences the [government's] sudden reversal of position inflicted on [a person]."288

Furthermore, exercises of prerogative powers may be constrained by a formal written instrument. For example, Orders-in-Council prescribe the relevant considerations for the issuance and revocation of passports, ${ }^{289}$ and for the designation of certain harbour waters as controlled access zones for national defence purposes. ${ }^{290}$ Substantive review of delegated authority under such instruments is analogous to substantive review of statutory powers. Thus, in El Shurafa, the Federal Court's reasonableness review of Passport Canada's exercise of passport issuance powers under the Canadian Passport Order was indistinguishable from reasonableness review of the exercise of a statutory power. ${ }^{291}$

The contextual factors that constrain discretion in particular cases cannot be enumerated exhaustively. However, jurisprudence identifying factors that constrain discretionary statutory powers can also guide reasonableness review of exercises of prerogative powers.

\section{g. Applying Reasonableness Review to Determinations \\ About the Existence and Scope of Prerogative Powers}

So far, I have argued that courts should apply the contextual reasonableness standard to exercises of prerogative powers. Contemporary administrative law principles also suggest that courts must not have a monopoly on defining the scope of prerogative powers. Although these powers are defined by the common law, the government actors who exercise them have considerable expertise relative to the courts as to how the scope of those powers ought to be understood in light of changing social, economic, and political realities.

An administrative actor's interpretation of its constituent statute is reviewable on a reasonableness standard, ${ }^{292}$ unless the interpretive question falls under one of the exceptional categories warranting correctness review outlined above. ${ }^{293}$ Moreover, the possibility of treating such questions as jurisdictional, and thus reviewable for correctness, has been all but ruled out. ${ }^{294}$ Consistent with these principles, courts review administrative interpretations of

$R v$ Mabior, 2012 SCC 47, [2012] 2 SCR 584 at para 43.

Baker, supra note 106 at paras 69-71.

Mount Sinai, supra note 122 at para 63, Binnie J.

Canadian Passport Order, SI/81-86, (1981) C Gaz II, 1852, online: <laws-lois.justice.gc.ca/eng/regulat ions/SI-81-86/>.

Controlled Access Zone Order (Halifax, Esquimalt and Nanoose Harbours), SI/2003-2, online:

$<$ laws.justice.gc.ca/eng/regulations/SI-2003-2/>.

El Shurafa, supra note 277 at paras 28, 39-46.

ATA, supra note 2 at para 41.

Ibid at para 30; McLean, supra note 231 at para 25.

McLean, ibid, citing ATA, ibid at para 34.
} 
the scope of codified prerogative powers on a reasonableness standard ${ }^{295}$ In Agraira, the Supreme Court of Canada reviewed a minister's interpretation of the term "national interest" as a ground for granting exceptional relief from immigration legislation on the reasonableness standard, even though the Minister had not expressly interpreted that term. ${ }^{296}$ The Supreme Court determined the implied interpretation based on the Minister's ultimate decision and the administrative guidelines in place. The Supreme Court then considered the reasons that could have been offered in support of the Minister's implied interpretation, allowing it to conclude that the interpretation was reasonable. ${ }^{297}$ If reasonableness review applies to administrative interpretations of the scope of codified prerogative powers, it should equally apply to administrative interpretations of the existence and scope of prerogative powers defined at common law. Where administrative actors do not expressly interpret the scope of the prerogative powers under which they purport to act, courts can seek out their implicit interpretations, as they do with statutory powers.

It may be objected that determining the existence and scope of prerogative powers is a matter uniquely suited to the courts, because it involves developing the common law. Such an objection, however, is untenable, since courts already apply reasonableness review to certain administrative interpretations of equitable and common law rules. ${ }^{298}$

Nevertheless, just as reasonableness review of statutory interpretation differs significantly from reasonableness review of the exercise of discretion, so too will it differ considerably between interpretations of the existence or scope, as compared to the exercise, of prerogative powers. The range of reasonable statutory interpretations is often limited because administrative statutory interpretations must conform "with the plain words of the provision, its legislative history, its evident purpose, and its statutory context." ${ }^{299}$ Similarly, prerogative powers must be grounded in demonstrable historical precedents, which will constrain their number and scope. As argued above, rule of law and democratic legitimacy deficiencies associated with prerogative powers support requiring the executive to demonstrate that obtaining statutory authorization would not be practicable before courts recognize the existence of a disputed prerogative power, or a novel interpretation of an established prerogative power. The application of a reasonableness standard simply means that courts will show deference to the executive's assessment of the feasibility of relying on statutory authority.

Additionally, the range of reasonable interpretations of the existence and scope of prerogative powers will be constrained by Charter values, because both administrative decision-makers ${ }^{300}$ and courts are required to "apply and develop the principles of the common law in a manner consistent with the fundamental values enshrined in the Constitution."301 
Therefore, administrative decisions about the existence and scope of prerogative powers should be reviewed for reasonableness, unless they fall under an exceptional category warranting correctness review (a possible example would be cases involving the division of powers, such as claims by provincial governments to be exercising the prerogative to enter treaties). ${ }^{302}$ Furthermore, those exceptional categories must not be interpreted as a license for wide-ranging correctness review. ${ }^{303}$ Accordingly, El Shurafa's holding that interpreting the scope of prerogative powers is "a constitutional question" warranting correctness review, "because it is about the separation of powers between the executive and legislative branches of government," 304 should be rejected. Judicial review is always about the separation of powers - perhaps even more so when courts are ensuring that the executive respects the limits of its statutory authority. The Federal Court's reasoning would therefore justify correctness review in all cases, an approach dramatically out of step with contemporary administrative law principles.

The general application of a reasonableness standard to judicial review of the existence, scope, and exercise of prerogative powers is consistent with the Supreme Court of Canada's rejection of the traditional rigid dichotomies between discretionary and non-discretionary decisions, ${ }^{305}$ as well as between legal and policy questions. ${ }^{306}$ Moreover, reasonableness review of the existence and scope of prerogative powers fosters an institutional dialogue in which courts can mitigate the rule of law deficiencies of those powers by more precisely articulating their scope and purpose, while showing deference to executive evaluations of the non-statutory powers required to further the public interest.

\section{Conclusion}

I have proposed that Canadian courts reform judicial review of the exercise of prerogative powers in three ways. First, courts should adopt a principled approach to defining prerogative powers that starts with distinguishing the Crown's prerogative powers from its natural person powers. Second, courts should abandon peculiar interest-based and subject matter justiciability tests in favour of a test that turns on the nature of the question. They should maintain a subject matter justiciability test only for exercises of prerogative powers that are integral to the democratic process. Third, courts should apply standard principles of administrative law to judicial review of the existence, scope, and exercise of prerogative powers. Implementing these reforms will allow the principle that the source of power is immaterial for the purposes of judicial review to become more than empty judicial rhetoric. It will also enable judicial review of the exercise of prerogative powers to express the judicial commitment to democracy and the rule of law.

The federal-provincial distribution of prerogative powers over foreign affairs is disputed (Gibran van Ert, "The Legal Character of Provincial Agreements with Foreign Governments" (2001) 42:4 C de D 1093 at 1116; Armand de Mestral, "The Provinces and International Relations in Canada" in JeanFrançois Gaudreault-DesBiens \& Fabien Gélinas, eds, The States and Moods of Federalism: Governance, Identity and Methodology (Cowansville, QC: Yvon Blais, 2005) at 313). 
